\title{
UNESCO, Palestine ANd ARChaeology in Conflict
}

\author{
DAVID KEANE AND VALENTINA AZAROV ${ }^{* *}$
}

\section{INTRODUCTION}

On 23 November 2011, Palestine became a member of the United Nations Educational, Scientific and Cultural Organization ("UNESCO"), and acceded to and ratified a number of UNESCO's Conventions. ${ }^{1}$ Some observers view this membership as decisive, or at least significantly dispositive, in the debate on the international recognition of Palestinian statehood. ${ }^{2}$ UNESCO is characterized as a springboard by which Palestine can further recognition of its international sovereignty, which, at the present time, is inexorably stalled. However, this recognition is not without challenge-for example, the Prosecutor of the International Criminal Court has not recognized Palestine's acceptance of the Court's jurisdiction. ${ }^{3}$ UNESCO has, in turn, descended into a budgetary crisis with the withdrawal of funding from the U.S. and other states, which represent twenty-two percent of its budget: ${ }^{4}$ In February 2012, UNESCO responded to this crisis with a plan to "re-engineer" the organization, implicitly confirming that it will not allow any revocation of the Palestinian membership vote, ${ }^{5}$ despite a campaign to "un-admit" Palestine. ${ }^{6}$ This paper analyzes the legal consequences of

\footnotetext{
** Mr. Keane is a Senior Lecturer in Law, Middlesex University, London; Ms. Azaraov is a Lecturer in Human Rights and International Law, Al-Quds Bard College, Al-Quds University, Palestine. The authors would like to thank Shane Darcy and Michael Kearney for their comments. The authors assume all responsibility for the content cited in this paper. Please direct comments to d.p.keane@mdx.ac.uk; valentinaazarov@gmail.com.

1. Palestine, United Nations Educational, Scientific and Cultural Organization, http: //www.unesco.org/new/en/unesco/worldwide/arab-states/Palestine/ (last visited Mar. 4, 2013).

2. William A. Schabas, Relevant Depositary Practice of the Secretary-General and Its Bearing on Palestinian Accession to the Rome Statute, PHD STUdiES IN HUMAN Rights (Nov. 3, 2011), http:// humanrightsdoctorate.blogspot.com/2011/11/relevant-depositary-practice-of.html.

3. Office of the Prosecutor, Situation in Palestine, INT'L CRIM. CT. ๆף 5-7 (Apr. 3, 2012) [hereinafter Situation in Palestine], available at http:/www.icc-cpi.int/NR/rdonlyres/C6162BBF-FEB94FAF-AFA9-836106D2694A/284387/SituationinPalestine030412ENG.pdf.

4. See, e.g., Steven Erlanger \& Scott Sayare, UNESCO Accepts Palestinians as Full Members, N.Y. TIMES, Nov. 1, 2011, at A8. Canada, which contributes about $\$ 10$ million to UNESCO per year, also withdrew UNESCO funds. Canada Won't Cover UNESCO Budget Gaps, CBC NEWS: WORLD (Nov. 1, 2011), http://www.cbc.ca/news/world/story/2011/11/01 /palestinians-un-agencies-unesco.html.

5. Director-General of the U.N. Educational, Scientific and Cultural Organization (UNESCO), Financial Situation of the Organization and its Implications for the Implement of Document $36 \mathrm{C} / 5, \uparrow 2$, U.N. Doc. $189 \mathrm{EX} / 15$ (Feb. 7, 2012), available at http://unesdoc.unesco.org/images/0021/002152/2152 02e.pdf.

6. See, e.g., Jim Zanotti, U.S. Foreign Aid to the Palestinians, Cong. ReSEarch Serv. 2223 (2013), available at http://www.fas.org/sgp/crs/mideast/RS22967.pdf.
} 
Palestine's membership in UNESCO and its ratification of UNESCO conventions through an examination of the protections afforded by the UNESCO treaty framework governing cultural, amongst other forms of, heritage. This is particularly relevant as Palestine's application for UNESCO membership took place in the context of what are termed the Palestinian U.N. initiatives, intended to further Palestine's status and activate its rights as a state in the international legal order. $^{7}$ The initiatives manifested in a resolution adopted by the U.N. General Assembly on 29 November 2012 "upgrading" Palestine's observer status. ${ }^{8}$

For more than a century, Palestinian cultural heritage and property has been the subject of capture and destruction by other states. Palestine's accession to various UNESCO conventions testifies to the effect that no other sovereign controls its cultural heritage and property. Palestinians have habitually asserted internationally-recognized principles as a point of departure in "final status" negotiations on what is termed the "archaeology file," yet have been unable to maintain complete control of such property. Ahmad A. Rjoob of the Palestinian Ministry of Tourism and Antiquities describes Palestinian cultural heritage as "one of the most intensively abused, excavated and subsequently disturbed worldwide," ${ }^{\prime 10}$ a result of more than a century of management from different administrations, each with its own methods of research and distinct political purpose. "The Palestinian Ministry of Tourism and Antiquities and Israeli sources estimate that between 1967 and 1992 about 200,000 artifacts were removed from the occupied Palestinian territory annually," with approximately 120,000 removed each year since 1995. ${ }^{11}$ This hemorrhaging of Palestinian cultural property is occurring in a context where archaeology has been used by Israel "as a pretext to gain territorial control" and exercise sovereign rights "over Palestinian lands [in order] to further its settlement enterprise" and exploit natural resources. ${ }^{12}$

7. See Orna Ben-Naftali, Aeyal M. Gross \& Keren Michaeli, Illegal Occupation: Framing the Occupied Palestinian Terrority, 23 BERKELEY J. INT'L L. 551, 552 (2005). The aim of the initiatives is to end Israel's unlawful advancement of sovereignty claims over territory beyond its borders. See also Orna Ben-Naftali, PathoLAWgical Occupation: Normalizing the Exceptional Case of the Occupied Palestinian Territory and Other Legal Pathologies, in INTERNATIONAL HUMANITARIAN LAW AND INTERNATIONAL. HUMAN RIGHTS LAW 129, 149-57 (Orna Ben-Naftali ed., 2011).

8. G.A. Res. 67/28, ๆף 1-2, 4, 6, U.N. Doc. A/RES/67/L.28 (Nov. 26, 2012). The resolution, adopted by a majority of $138-9$ with 41 countries abstaining, granted the State of Palestine "nonmember state status" in the United Nations. G.A. Res. 69/17, fग 1-2, 4-6, U.N. Doc A/RES/67/19 (Nov. 29, 2012).

9. Gabriel Fahel, Repatriating Palestinian Patrimony: An Overview of Palestinian Preparations for Negotiations on Archaeology, 2 PRESENT PASTS 19 (2010), available at http://www.presentpasts.in fo/article/view/pp.19/41.

10. Ahmed A. Rjoob, Contested Management of Archaeological Sites in the Hebron District, 2 PRESENT PASTS 24 (2010), available at http://www.presentpasts.info/article/view/pp.24/36.

11. Fahel, supra note 9.

12. Id. For instance, in a recent judgment the Israeli Supreme Court upheld Israel's right as an occupier to exploit the stone quarries in the Palestinian territory without limits, allowing Israel to sell and use the product of exploitation on the private Israeli market. HCJ 2164/09 Yesh Din v. Commander of the Israeli Forces in the West Bank, at 19 [2011] (Isr.), available at http://www.yeshdin.org/userfiles/file/\%D7\%94\%D7\%9B \%D7\%A8\%D7\%A2\%D7\%95\%D7\%AA $\% 20 \% D 7 \% 93 \% D 7 \%$ 
Section II traces the history of archaeological laws and practices in Palestine, from the Ottoman era to contemporary Israeli military orders. Section III examines the rules governing the protection of cultural property during military occupation under the aegis of the 1954 Hague Convention for the Protection of Cultural Property in the Event of Armed Conflict, ${ }^{13}$ and the consequences of future Palestinian ratification of the Convention and its 1999 Second Protocol. ${ }^{14}$ Section IV tracks the illicit trade in antiquities from Palestine, and the potential effects that ratification of two instruments would have on regulation and restitutionparticularly, the 1970 UNESCO Convention on the Means of Prohibiting and Preventing the Illicit Import, Export and Transfer of Ownership of Cultural Property, ${ }^{15}$ and 1995 UNIDROIT Convention on Stolen or Illegally Exported Cultural Objects. ${ }^{16}$ Section $\mathrm{V}$ focuses on the underwater cultural heritage off the coast of Gaza and the maritime zones of legal control granted by the 2001 Convention on the Protection of the Underwater Cultural Heritage, the first international treaty that Palestine has ratified. ${ }^{17}$ Finally, Section VI assesses the consequences of UNESCO membership, including whether membership of a U.N. agency means that Palestine can ratify instruments outside of UNESCO's competence.

\section{DOMESTIC LAW AND ARCHAEOLOGY}

The era of Byzantine pilgrimage to the Middle East saw church officials encourage the acquisition of relics, and " $[\mathrm{b}] \mathrm{y}$ the end of the fourth century C.E., the export ... of relics ... had reached enormous proportions." ${ }^{18}$ This Christian interest, which spanned the Muslim conquest from the 7 th century C.E. onwards, gave way to a secular interest in the region with the "growth of antiquarianism in the 18th century." 19 In this period virtually all areas of archaeological concern were under Ottoman rule. ${ }^{20}$ Regulations on antiquities were first issued in $1869,{ }^{21}$

$99 \% \mathrm{D} 7 \% 9 \mathrm{~F} / \mathrm{psak}$.pdf. The principal basis for the Court's rationale was a "dynamic" interpretation of the usufruct rule, enshrined in Article 55 of the 1907 Hague Regulations. Id. at 5-19.

13. Convention for the Protection of Cultural Property in the Event of Armed Conflict, May 14, 1954, 249 U.N.T.S. 240 [hereinafter 1954 Hague Convention].

14. Second Protocol to the Hague Convention of 1954 for the Protection of Cultural Property in the Event of Armed Conflict, Mar. 26, 1999, 38 I.L.M. 769 [hereinafter 1999 Second Protocol].

15. Convention on the Means of Prohibiting and Preventing the Illicit Import, Export and Transfer of. Ownership of Cultural Property, Nov. 14, 1970, 823 U.N.T.S. 232 [hereinafter 1970 UNESCO Convention].

16. International Institute for the Unification of Private Law, UNIDROIT Convention on Stolen or Illegally Exported Cultural Objects, June 24, 1995, 34 I.L.M. 1322 [hereinafter 1995 UNIDROIT Convention].

17. Convention on the Protection of the Underwater Cultural Heritage, Paris, Nov. 2, 2001, 41 I.L.M. 40 (entered into force Mar. 8, 2012) [hereinafter Underwater Heritage Convention].

18. Morag M. Kersel, The Trade in Palestinian Antiquities, 33 JERUSALEM Q. 21, 21-24 (2008) [hereinafter Kersel, The Trade in Palestinian Antiquities].

19. Id. at 23.

20. G. R. H. Wright, Archaeology and Islamic Law in Ottoman Cyprus, in CYPRUS IN THE 19TH CENTURY AD: FACT, FANCY AND FICTION 261, 261-67 (Veronica Tatton-Brown ed., 2001). 
and the Ottoman rulers enacted an Antiquities Law in 1874 (Asari-Atika), including provisions that have subsequently become canonical in the legal protection of antiquities. $^{22}$ Prior to this there is no record of a sui generis antiquities law for Ottoman territories, with the exception of particular or individual archaeological activity regulated via an imperial decree, or firman, from the Sultan. ${ }^{23}$ In 1884, a further law "established national patrimony over all artifacts in the Ottoman Empire" and required excavation permits. It deemed all artifacts discovered "the property of the National Museum in Constantinople" and prohibited their export without its permission. ${ }^{24}$ These laws were undermined by the lack of enforcement to prevent widespread ransacking of ancient tombs and other forms of illicit digging. As one observer noted, "under Turkish rule everything was prohibited; but everything was possible." 25

The territorial shape of Palestine, long left undefined, was determined by the archaeologists of the Survey of Western Palestine, ${ }^{26}$ sponsored by the Londonbased Palestine Exploration Fund and published in 1880. The introduction to the Survey notes that it contains "all the information that is usually found in a topographical map,"27 and it would form the contours of the post-World War I British Mandate over Palestine. ${ }^{28}$ The Mandate Period oversaw the establishment of the Palestine Archaeological Museum and the Department of Antiquities of Palestine in $1920{ }^{29}$ The antiquities law was re-drafted and the resultant Antiquities Ordinance of 1920 -re-issued in $1929^{30}$-replaced the existing 1884

21. Nicholas Stanley-Price, The Ottoman Law on Antiquities (1874) and the Founding of the Cyprus Museum, in CYPRUS IN THE 19TH CENTURY AD: FACT, FANCY AND FICTION 267, 267-72 (Veronica Tatton-Brown ed., 2001).

22. Wright, supra note 20 , at 265 . Its provisions included vesting of all antiquities in the state, establishment of a responsible department, no excavation without a permit, proper recording of finds and no export without special permission.

23. Id. at 263 .

24. Kersel, The Trade in Palestinian Antiquities, supra note 18, at 24 (arguing that the 1884 Law "could be construed as legalized cultural imperialism-motivated by the Ottoman Empire's desire to appropriate material from its territories rather than for the preservation of the archaeological legacy of the region").

25. Shimon Gibson, British Archaeological Institutions in Mandatory Palestine 1917-1948, 131 PALESTINE EXPLORATION Q. 115, 136 (1999).

26. Neil Asher Silberman, Structuring the Past: Israelis, Palestinians and the Symbolic Authority of Archaeological Monuments, in THE ARChaEOLOGY OF ISRAEL: CONSTRUCTING THE PAST, INTERPRETING THE PRESENT 62, 67 (Neil Asher Silberman \& David Small eds., 1997).

27. Trelawney Saunders, AN INTRODUCTION TO THE SURVEY OF WESTERN PALESTINE: ITS WATERWAYS, PlaINS, \& HighLANDS 4-5 (1881) (noting that "[w]ithout such a map of the country as the [Palestine Exploration] Fund has produced, the student of the History of Palestine, sacred and profane, ancient, medieval and modern alike, had to grope about in the midst of uncertainty.").

28. A 1918 Memorandum on Ancient Sites and Military Operations in Palestine from the chairman of the Palestine Exploration Fund to the Secretary of State for War emphasized that "many of the ancient sites may turn out to be strategic points of vantage in the military operations of today." See Gibson, supra note 25 , at $126-27$.

29. Id. at 115 .

30. George hill, Treasure Trove in Law and Practice: From the Earliest Time to the PRESENT DAY 270 (1936); Kersel, The Trade in Palestinian Antiquities, supra note 18, at 26. 
Ottoman law, representing a "more relaxed legislation that allowed for flexibility in the export of antiquities." 31 The Antiquities Ordinance would subsequently become the basis for the Israeli and Jordanian Antiquities Laws, ${ }^{32}$ with the latter being used as its legal basis by the contemporary Department of Antiquities of the Palestine Authority. ${ }^{33}$

The Antiquities Ordinance laid down that "all antiquities whether of a moveable character or fixed in the soil which shall be hereafter discovered shall be deemed to be the property of the Government," meaning the Civil Government of Palestine, ${ }^{34}$ but afforded provisions for a "fair division" of finds between the Palestine Museum and foreign institutions undertaking excavations. ${ }^{35}$ This was the result of intense lobbying by the British archaeological establishment to implement more liberal antiquities laws in territories under British dominion and in stark contrast to comparable legislation in European states. ${ }^{36}$ After the establishment of the State of Israel in May 1948:

[T]he West Bank came under the guardianship of the Hashemite Kingdom of Jordan while the Gaza Strip was administrated by Egypt, and the Antiquities Ordinance of 1929 remained in effect in both places. Then in 1966 the temporary Antiquities Law . . . was enacted by the Kingdom of Jordan and imposed on the West Bank. This law declared that antiquities are considered the national property of [Jordan]. . . . Since the establishment of the Palestinian Ministry of Tourism and Antiquities in 1994, the Ministry . . has drafted its own version of a national antiquities law ... [which has yet to be] enacted. . . [As a result] the Jordanian Antiquities Law of 1966 is still applicable in the Palestinian Territories today. ${ }^{37}$

Following the Israeli occupation of the West Bank and Gaza Strip in 1967, Israel governed the territory through the military's commander and civil administration, as it was the Occupying Power. The law that came to apply in the Palestinian territory under the rule of the Israeli occupier was an amalgamation of the old Ottoman and Jordanian law, some existing Palestinian law, and predominantly military legislation issued by the Israeli military commander and

31. Magnus T. Bernhardsson, ReClaiming a Plundered Past: ARCHaEology and Nation BUILDING IN MODERN IRAQ 124 (2005).

32. The contemporary legal antiquities trade in Israel is discussed in Section IV infra. See also Kersel, The Trade in Palestinian Antiquities, supra note 18, at 26 ("[T]he definition of buying and selling of artefacts is clearly spelled out [in the Antiquities Ordinance] . . . with a basic definition of "to deal' . . [ [and] guidelines for obtaining licenses to deal in and export antiquities," with many of these requirements in force in the current trade in Israel.).

33. Gibson, supra note 25 , at 131.

34. Id. at 137.

35. Id. (citing Chapter V, Clause 30 of the Antiquities Ordinance 1920).

36. BERNHARDSSON, supra note 31 , at 126.

37. Salah H. Al-Houdalieh, Archaeological Heritage and Related Institutions in the Palestinian National Territories 16 Years After Signing the Oslo Accords, 2 PRESENT PASTS 20 (2010), available at http://www.presentpasts.info/article/view/pp.20. 
used to control a long list of areas of Palestinian daily life under occupation. "[R]esponsibility for archaeology transferred to two Israeli Staff Officers for Archaeology (SOAs): one for the Gaza Strip and another for the West Bank excluding East Jerusalem." 38

The archaeological legal framework remained largely intact with crucial modifications through military orders aimed at licensing, excavations, and the trade in antiquities." "Military orders are decrees issued by the military commander" which become law for every Palestinian living in the area immediately upon issuance. ${ }^{40}$ For archaeology, "[t]he most important was Military Order No. 119 of 1967, which revoked many of the principles of [the British Mandate Antiquities Ordinance]" and placed responsibility for antiquities under military officials. ${ }^{41}$ According to this "Order Concerning Law Of Antiquities," all appointments made or jurisdiction granted by the Jordanian government pertaining to the management of antiquities were cancelled, and responsibilities transferred to the Israeli official-in-charge, who could enact new orders where needed. ${ }^{42}$

The SOA, or, the Staff Officer for Archaeology in the Civil Administration, is the Israeli army officer in charge of archaeology in the occupied West Bank. The position was held for some twenty-five years by Dr. Yitzhak Magen, which led one archaeologist to call the post "a lifetime appointment, completely without precedent in the Israeli public service." body by character . . . headed by a civilian who is an expert in the field, but who operates within an army framework, such as the Civil Administration, and on the basis of military orders." in occupied territories, other than rescue digs, and the findings may not be removed from those territories ... . [the SOA] holds sole responsibility for all archaeological matters beyond the Green Line."45

Almost immediately following the 1967 war and the Israeli occupation of Palestinian territory, archaeological surveys were conducted in the West Bank, the Gaza Strip and East Jerusalem. ${ }^{46}$ The SOA is the only authority that can issue

38. Rjoob, supra note 10.

39. Id.

40. NEVE Gordon, ISRAEL's OCCUPATION 27 (2008). See also DAVID KRETZMER, THE OCCUPATION OF JUSTICE: THE SUPREME COURT OF ISRAEL AND THE OCCUPIED TERRITORIES 27-29 (2002).

41. Hamdan Taha, The Current State of Archaeology in Palestine, 2 PRESENT PASTS 17 (2010), available at http://www.presentpasts.info/article/view/pp.17/34.

42. Study Guide: Israeli Military Orders in Use in Adjacent Palestinian Occupied Territories, ISRAEL LAW RESOURCE CENTER (Feb. 2007), http://www.israellawresourcecenter.org/Israelmilitar yorders/studyguide/sgmol.htm.

43. Meron Rapoport, Buried Treasure That's Kept in the Dark, HAARETZ (Dec. 17, 2006), http://www.haaretz.com/print-edition/features/buried-treasure-that-s-kept-in-the-dark-1.207435.

44. Id.

45. Id.

46. Nadia Abu El-HaJ, Facts on the Ground: archaeological Practice and TERRITORIAL SELF-FASHIONING IN ISRAELI SOCIETY 244 (2001). 
excavation licenses, and the vast majority of these it issues to itself. ${ }^{47}$ Further, it $^{4}$ oversees and conducts the excavations and selectively publishes results in its inhouse publications. ${ }^{48}$ The SOA has not been subordinated to the Israel Antiquities Authority. ${ }^{49}$ The result "is that the SOA has become an autonomous, highly centralized unit." 50 In particular, these military orders give the SOA "a free hand to conduct excavations, confiscate land and transfer objects throughout the West Bank without oversight by anyone in the occupation authority," 51 with the result that hundreds of excavations in the occupied Palestinian territory were authorized. Rjoob highlights the opacity of the SOA's activities:

No one knows where excavations are taking place or the whereabouts of finds. There is no obligation to report archaeological activities, or if there is, it is a selective choice based on the excavator's whim or the aims and priorities of the SOA. As a result, most archaeological excavations in the West Bank do not have publications. ${ }^{52}$

Under the 1995 PLO-Israel Interim Agreements, known as the Oslo Accords," "the Palestinian Authority took over responsibility for archaeology in Areas ' $A$ ' and ' $B$ ', representing about $40 \%$ of the Occupied Palestinian territories," the first time the Palestinians could control part of their own cultural heritage. ${ }^{54}$ While the powers and responsibilities over archaeology in some parts of Area C were to be transferred to Palestinian institutions, with the goal of eventually including all of the West Bank and Gaza, this arrangement has never been implemented. ${ }^{55}$ All excavations in Area $\mathrm{C}$-more than sixty percent of the West Bank-have been conducted under the SOA, with ninety-five percent of these conducted by the SOA himself. ${ }^{56}$ According to Rafi Greenberg, overall some " 1,100 excavation permits were issued for digs . . a at 700 sites in the West Bank,

47. RAPHAEL GREENBERG \& ADI KEINAN, ISRAELI ARCHAEOLOGICAL ACTIVITY IN THE WEST BANK 1967-2007: A SOURCEBOOK 6 (2009).

48. Id.

49. Rapoport, supra note 43. The Israeli Antiquities Authority was established by the Antiquities Authority Law of 1989, which repealed the earlier Antiquities Law of 1978. See also Nidal Sliman, The Protection of Cultural Property in Occupied East Jerusalem: Archaeological Excavations and Removal of Cultural Property, in XXXV THESAURUS ACROASIUM: MULTICULTURALISM AND INTERNATIONAL LAW 341, 353 (Kalliopi Koufa ed., 2007).

50. GREENBERG \& KEINAN, supra note 47, at $6 \mathrm{n} .1$.

51. Rjoob, supra note 10.

52. Id.

53. What was the 1995 Oslo Interim Agreement?, PROCON.ORG (2013), http://israelipalestinian.pr ocon.org/view.answers.php?questionID $=000439$. The Agreements codify a set of practical arrangements for the daily administration of the occupied territory by the Israeli military government and the Palestinian Authority, a body of the PLO created for this purpose. As such, their implementation must be in line with the international law of belligerent occupation. Eyal Benvenisti, Responsibility for the Protection of Human Rights Under the Interim Israeli-Palestinian Agreements, 28 ISR. L. REV. 297, $297-98$ (1994). See also Antonio Cassese, The Israel-PLO Agreement and SelfDetermination, 4 EUR. J. INT'L L. 564, 564 (1994).

54. Rjoob, supra note 10.

55. Taha, supra note 41.

56. Rjoob, supra note 10. 
not including East Jerusalem," and were largely without documentation of any kind, which exists for only approximately fifteen percent of the digs. ${ }^{57}$ Consequently, he describes Israel's behavior in the territories as "an archaeological heart of darkness." 58

Archaeology has been, and continues to be, used as a pretext for the procurement of territory. The presence of archaeological or biblical sites is used to justify confiscating Palestinian lands and building illegal settlements. ${ }^{59}$ For example, the construction of the road leading to the illegal settlement outpost Migron was based on the licensing of an archaeological dig. ${ }^{60}$ Land next to the Palestinian village of Susiya Al-Qadime was confiscated on the pretext of archaeological digs and a settlement established nearby, when a 4th century synagogue was uncovered by Israeli excavations in the 1970s. ${ }^{61}$ The occupation authorities declared the area to be an archaeological park, expelling local residents from their land who live in tents on a hill between the settlement and the archaeological park. ${ }^{62}$ The Palestinians who were barred from accessing the Ein Al-Kis freshwater spring near the village of Nabi Saleh, on the unfounded grounds that it was an archaeological site, petitioned the Israeli High Court together with the rights group Yesh Din, whose attorney noted that: "The authorities are using archaeological claims as an excuse to prevent the petitioners from accessing their lands- based on considerations that have nothing to do with archaeology."63

An independent Palestinian approach to archaeology, considered today to be "surviving, if not thriving," began in the late 1970s. ${ }^{64}$ The Palestinian Department of Antiquities and Cultural Heritage, re-established in 1994, is considered to be a revival of the Department of Antiquities that was established in 1920 under the British Mandate and terminated by the political events of $1948 .{ }^{65}$ A number of excavations have been carried out, including collaborations with foreign experts and institutions. ${ }^{66}$ Due to the different sets of existing archaeological legislation inherited by the Department, it is presently working on a draft of the Law of Cultural Heritage, which "resituates the archaeology of Palestine within the

57. Rapoport, supra note 43.

58. $I d$.

59. Adel H. Yahya, Looting and "Salvaging" the Heritage of Palestine, 2 PRESENT PASTS 26 (2010), available at http://www.presentpasts.info/article/view/pp.26.

60. Migron - Timeline of an Illegal Outpost, PEACE Now, http://peacenow.org.il/eng/content/m igron-timeline-illegal-outpost (last visited Feb. 10, 2013).

61. Nadia Abu-Zahra, IDs and Territory: Population Control for Resource Expropriation, in WAR, CITIZENSHIP, TERRITORY 303, 322 (Deborah Cowen \& Emily Gilbert eds., 2008).

62. See also Ehud Krinis, David Shulman \& Neve Gordon, Facing an Imminent Threat of Expulsion, COUNTERPUNCH (June 22-24, 2007), http://www.counterpunch.org/2007/06/22/facing-animminent-threat-of-expulsion/.

63. Tovah Lazaroff, Court Asked to Ensure Palestinian Farmers' Water Access, JERUSALEM POST, http://www.jpost.com/MiddleEast/Article.aspx?id=199822\&R=R3 (last updated Dec. 17, 2010, $01: 14$ PM).

64. GREENBERG \& KEINAN, supra note 47 , at 7.

65. Taha, supra note 41 .

66. GREENBERG \& KeINAN, supra note 47 , at 7. 
universe of the international discipline." ${ }^{, 67}$ At the same time the priority is to combat the looting of archaeological sites during occupation, hundreds of which continue to be plundered to service the active illegal trade in cultural property, ${ }^{68}$ as well as potentially setting the ground for a legal trade in antiquities in Palestine, although this issue is undecided. ${ }^{69}$

\section{INTERNATIONAL LAW AND ARCHAEOLOGY}

Israeli involvement in the management of Palestine's cultural heritage since the occupation of the Palestinian territory in 1967 has been intense, requiring investigation in terms of its compliance with international humanitarian law. The 1954 Hague Convention for the Protection of Cultural Property in the Event of Armed Conflict and its First Protocol ("1954 Hague Convention"), ${ }^{70}$ much of which constitutes customary international law, ${ }^{71}$ complements and reinforces the protection afforded to cultural property by the laws of war found in the 1949 Fourth Geneva Convention and 1907 Hague Regulations." "The prohibition on pillage of cultural property is lex specialis to the general prohibition of pillage" in Article 33 of the Fourth Geneva Convention, intended to encompass affirmative duties of the Occupying Power to prevent private groups and individuals from undertaking such acts. ${ }^{73}$ The provisions on the protection of private and public property in occupied territory also includes the "property of the communes, that of religious, charitable, and educational institutions, and those of arts and science," and strictly prohibit all forms of its use, save for temporary requisitioning of movable property. ${ }^{74}$ The protection framework, defined in Article 4 of the 1954 Hague Convention, requires that State Parties ensure respect for cultural property

67. Taha, supra note 41 .

68. Id.

69. Kersel, The Trade in Palestinian Antiquities, supra note 18, at 32.

70. First Protocol to the Convention for the Protection of Cultural Property in the Event of Armed Conflict, May 14, 1954, 249 U.N.T.S. 215 [hereinafter First Protocol].

71. JEAN-Marie HenCKaERTS \& LOUISE DOSWALD-BECK, CUSTOMARY INTERNATIONAL HUMANITARIAN LAw, VOLUME I: RULES 129 (2005). The annotated supplement to the U.S. Naval Handbook holds that, whilst the U.S. is not a party to the 1954 Hague Convention, it considers it to reflect customary law. ANNOTATED SUPPLEMENT TO THE COMMANDER'S HANDBOOK ON THE LAW OF NAVAL OPERATIONS 297-305 (A.R. Thomas \& James C. Duncan eds., 1999) [hereinafter U.S. NAVAL HANDBOOK], available at http://permanent.access.gpo.gov/gpo3917/Naval-War-College-vol-73.pdf.

72. Protocol Additional to the Geneva Conventions of 12 August 1949 , and Relating to the Protection of Victims of International Armed Conflicts arts. 52-53, June 8, 1977, 1125 U.N.T.S. 3 (entered into force Dec. 7, 1978) [hereinafter Protocol I].

73. Yutaka arai-Takahashi, The Law of Occupation: Continuity and Change of INTERNATIONAL HUMANITARIAN LAW, AND ITS INTERACTION WITH INTERNATIONAL HUMAN RIGHTS LAW 246-47 n.28 (2009).

74. Convention (IV) Relative to the Protection of Civilian Persons in Time of War arts. 55-56, Aug. 12, 1949, 75 U.N.T.S. 287 [hereinafter Fourth Geneva Convention 1949]; Convention (IV) Respecting the Laws and Customs of War on Land arts. 53, 55-56, Oct. 18, 1907, 36 Stat. 2277 [hereinafter Hague Regulations 1907]; Convention (II) with Respect to the Laws and Customs of War on Land and its Annex arts. 53, 56, July 29, 1899, 32 Stat. 1779 [hereinafter Hague Regulations 1899]; ARAI-TAKAHASHI, supra note 73 , at 247-48. 
by shielding what is a broadly defined category of property from attacks and other uses "which are likely to expose it to destruction or damage," unless "military necessity imperatively requires such a waiver." 75 It further requires the "prohibit[ion], prevent[ion] and [cessation]" of any acts of "vandalism directed against ... cultural property." 76 It has been supplemented by the enhanced protection regime in the 1999 Second Protocol. ${ }^{77}$

Israel is a party to the 1954 Hague Convention and its First Protocol, ${ }^{78}$ but is not a party to the 1999 Second Protocol. The International Court of Justice has affirmed the applicability of international humanitarian and human rights law conventions to which Israel is a party, including the Fourth Geneva Convention and the 1954 Hague Convention, to its activities in the Palestinian territory. ${ }^{79}$ Despite Israel's obligations under these instruments, since 1967, and especially during the Palestinian uprising in 2000, Israel has damaged and destroyed Palestinian historical, cultural and religious sites throughout the occupied Palestinian territory. ${ }^{80}$ For instance, the Israeli military operations in the Old City of Nablus in 2002 resulted in extensive damage of cultural heritage, including structures dating to the Roman, Byzantine and Ottoman eras. ${ }^{81}$ Sliman notes that Jerusalem is a particularly stark example, including the past "seizure of historical and religious buildings, such as the Palestinian Archaeological Museum" and the razing of the Moroccan Quarter in the old city, which echoed the destruction of the Jewish Quarter by Jordanian forces in $1948 .^{82}$

A number of continuing projects, administered by the Israel Antiquities Authority, are a source of serious concern among archaeologists. The agreement

75. 1954 Hague Convention, supra note 13, arts. 4(1)-(2).

76. Id. art. 4(3).

77. See JiRI Toman, The Protection of Cultural Property IN the Event OF ARMED 236-41 (2006) (providing an account of the range of UNESCO initiatives that led to the drafting of the 1999 Second Protocol).

78. See 1954 Hague Convention, supra note 13; Convention for the Protection of Cultural Property in the Event of Armed Conflict with Regulations for the Execution of the Convention, UNESCO.ORG, http://www.unesco.org/eri/la/convention.asp? $\mathrm{KO}=13637$ \&language=E\&order=chrono (last visited Mar. 5, 2013); Protocol to the Convention for the Protection of Cultural Property in the Event of Armed Conflict, UNESCO.ORG, http:/www.unesco.org/eri/la/convention.asp?KO=15391 \&an guage $=\mathrm{E} \&$ order $=$ alpha (last visited Mar. 5, 2013).

79. Legal Consequences of the Construction of a Wall in the Occupied Palestinian Territory, Advisory Opinion, 2004 I.C.J. 136, $\$ \uparrow$ 89, 101 (July 9).

80. See, e.g., Amnesty Int'l, Israel and the Occupied Territories: Shielded from Scrutiny: IDF Violations in Jenin and Nablus, at 57-58, AI Index MDE 15/143/2002 (Nov. 4, 2002) [hereinafter Amnesty Int'1, Israel], available at www.amnesty.org/en/library/asset/MDE15/143/2002/en/c4ef6642d7bc-11dd-b4cd-01 eb52042454/mde151432002en.pdf. See also Destruction of Palestinian Cultural Heritage: The Old City of Nablus, Negotiations AfFairs DEPaRTMENT: Palestine Liberation ORGANIZATION (2013), http://www.nad-plo.org/etemplate.php?id=69 (estimating damage at $\$ 54$ million USD).

81. Amnesty Int'l, Israel, supra note 80, at 57.

82. Sliman, supra note 49, at 354. See also Thomas Abowd, The Moroccan Quarter: A History of the Present, 7 JERUSALEM Q. 6, 8 (2000), available at http://www.jerusalemquarterly.org/ViewArticle. aspx?id=239. 
by the Israel Nature and Parks Authority to cede administration of the "City of David" park, located in the village of Silwan in occupied East Jerusalem, to Elad, an Israeli private group with political links involved in acquisition and settlement of property with no independently verifiable archaeological stature, has been a source of litigation. ${ }^{83}$ A UNESCO-appointed technical mission to the Old City of Jerusalem, which had reported to the World Heritage Committee, had concluded that Israel is acting in violation of international law in its archaeological excavations at the site and should abstain from undertaking any changes in the structures that would undermine its authenticity and integrity. ${ }^{84}$ Yet in October 2011, the Israeli High Court criticized the agreement but ultimately ruled that it was legal. ${ }^{85}$

A case that has similarly attracted media attention concerns the Simon Wiesenthal Centre's construction of a Museum of Tolerance in West Jerusalem. ${ }^{86}$ This construction involved excavations at the ancient Mamilla Cemetery with hundreds of exhumations of graves and remains and has been deemed a desecration of remains by the U.S. human rights organization Center for Constitutional Rights, which has filed a petition to U.N. bodies and the Swiss government on behalf of Palestinian descendants of those buried at the cemetery. ${ }^{87}$ Dating from the 7 th century, the British Mandate authorities pronounced the cemetery an antiquities site in $19444^{88}$ New photographic evidence released on 26 March 2012 showed the excavations are continuing, despite claims to the contrary. $^{89}$

Mamilla Cemetery is located in the western part of Jerusalem, which together with East Jerusalem and its environs, was declared to be an international corpus separatum under U.N. General Assembly Resolution 181 of 29 November $1947 .{ }^{90}$ Resolution 181 proclaims a special international regime for Jerusalem, and requires that: "[e]xisting rights in respect of Holy Places and religious buildings or sites shall not be denied or impaired," and that "Holy Places and religious buildings or sites shall be preserved. No act shall be permitted which may in any

83. Nir Hasson, Israeli NGO: Elad Group has "Veto" Power over Jerusalem's City of David, HAARETZ (Oct. 24, 2011), http://www.haaretz.com/print-edition/news/israeli-ngo-elad-group-has-vetopower-over-jerusalem-s-city-of-david-1.391619.

84. UNESCO, Report of the Technical Mission to the Old City of Jerusalem, fil 48-50, U.N. Doc. WHC-07/31.COM/INF.7A.2 (Feb. 27, 2007-Mar. 2, 2007), available at http://whc.unesco.org/uploads /news/documents/news-315-1.pdf.

85. Nir Hasson, High Court Critical of Elad Contract in City of David Park but Rules it Legal, HAARETZ (Oct. 27, 2011), http://www.haaretz.com/print-edition/news/high-court-critical-of-eladcontract-in-city-of-david-park-but-rules-it-legal-1.392184.

86. See, e.g., Rory McCarthy, Row Over Plan to Build Jewish Museum of Tolerance on Site of Muslim Cemetery, THE GUARDIAN (Feb. 10, 2010), http://www.guardian.co.uk/world/2010/feb/10/jewis h-museum-tolerance-muslim-cemetery.

87. Mamilla Cemetery in Jerusalem, CENTER FOR CONST. RTS., http://ccrjustice.org/Mamilla (last visited Feb. 11, 2013).

88. Id.

89. Id.

90. G.A. Res. 181 (I), at 146, U.N. Doc. A/RES/181(II) (Nov. 29, 1947). 
way impair their sacred character."91 Israel's Protection of Holy Places Law of 1967, which applies to all of Jerusalem, states that: "The Holy Places shall be protected from desecration,",92 yet the Center for Constitutional Rights deems Mamilla to be part of a pattern of systematic neglect of non-Jewish religious sites in the city. ${ }^{93}$ Such practices were condemned by U.N. Security Council Resolution 476 of 30 June 1980, which deplored "the persistence of Israel, in changing the physical character, demographic composition, institutional structure and the status of the Holy City of Jerusalem," a reference to the entirety of the city and not just East Jerusalem. ${ }^{94}$

Article 5 of the 1954 Hague Convention deals specifically with situations of belligerent occupation, requiring that states "as far as possible support the competent national authorities of the occupied country in safeguarding and preserving its cultural property." authorities are unable to perform their obligations, the Occupying Power shall, in close cooperation with the authorities, take only the most necessary measures of preservation. ${ }^{96}$ It is understood, therefore, that the Occupying Power will not administer cultural property, nor undertake preservation measures save in the exception where measures must be undertaken in close cooperation with the local authorities, ${ }^{97}$ compliant with the occupier's obligations to maintain the laws and institutions of the occupied territory. ${ }^{98}$ Even in these exceptional cases, an Occupying Power, who is absolutely prohibited from undertaking permanent changes in the occupied territory, is stringently limited to the execution of "the most necessary measures of preservation" to the end of preventing the deterioration of cultural property damaged in the course of hostilities. ${ }^{99}$

According to archaeologists, any excavation is also an act of destruction, whereby excavation "comes to possess a double meaning, as the recovery and understanding of archaeological remains and at the same time, the destruction of

91. Id. at $149, \uparrow 13$.

92. Protection of Holy Places Law, cited in Protection of Holy Places Law, 1967, ISR. MINISTRY OF FOREIGN AFFAIRS (June 30, 1998), http://www.mfa.gov.il/MFA/Peace+Process/Guide+to+the+Peac e+Process/Protection+of+Holy+Places+Law.htm.

93. Campaign to Pres. Mamilla Jerusalem Cemetery, Petrion for Urgent action on human RightS Violations IN MAMIlla CEMETERY By ISRAel 30-32 (2010), available at http://ccrjustice.org/files/MAMILLA\%20_FinalSubmission.pdf (including a statement of Deputy Mayor of Jerusalem Meron Benvinisti that pre-1948 Muslim burial sites have been "turned into garbage dumps, parking lots, roads and construction sites ... Open burial sites are scattered throughout the country, human bones are strewed about, and tombstones are shattered.").

94. S.C. Res. 476, U.N. Doc. S/RES/476 (Jun. 30, 1980).

95. 1954 Hague Convention, supra note 13 , art. $5(1)$.

96. Id. art. 5(2). The International Court of Justice held that this includes the occupying power's responsibility for his own actions as well as for those of others in the occupied territory. Armed Activities on the Territory of the Congo (Dem. Rep. Congo v. Uganda), 2005 I.C.J. 168, 224 (Dec. 19).

97. 1954 Hague Convention, supra note 13, art. 5(2).

98. Roger O'Keefe, The Protection of Cultural Property IN ARmed Conflict 309 (2006)

99. It will tend to be only in the most urgent circumstances. See, e.g., 1954 Hague Convention, supra note 13 , art. 5(2). 
the context and integrity of those remains."100 Consequently, Article 32 of UNESCO's Recommendation on International Principles Applicable to Archaeological Excavations, particularly on excavations in occupied territory, affirms: "any Member State occupying the territory of another State should refrain from carrying out archaeological excavations in the occupied territory." 101 While Article 5 of the 1954 Hague Convention codifies the occupier's obligation not to engage in excavations unless they fulfill certain criteria, Article 9(1)(b) of the 1999 Second Protocol positively restates this obligation by demanding that States Parties prohibit and prevent all excavations in occupied territory, save where it is strictly required to safeguard or preserve cultural property. ${ }^{102}$

O'Keefe suggests that Article 5 of the 1954 Hague Convention should be interpreted consistently with the prohibition on excavations in occupied territory in Article 9 of the 1999 Second Protocol. ${ }^{103}$ It might be deemed that the formulation of an express prohibition on excavations in the 1999 Second Protocol implies the absence of such a prohibition from the 1954 Hague Convention. However, this remains inconclusive since the 1999 provisions were intended to avoid any doubt. ${ }^{104}$ Arai-Takahashi notes what he terms "the controversy over the lacunae in the 1954 Convention," suggesting the possible existence of a prohibition in Article 5 of the 1954 Hague Convention. ${ }^{105}$ Vrdoljak states, even more firmly, that Article 9 only adds clarification to the obligation found in the spirit of Article $5 .^{106}$

Relevant state practice is seen only in the controversy over Israel's excavations in the Old City of Jerusalem, which resulted in widespread condemnation by High Contracting Parties and UNESCO's Executive Board resulting in the suspension of all UNESCO aid to Israel in $1974 .^{107}$ Therefore, despite the absence of an explicit prohibition on the conduct, sponsorship or authorization of excavations by the Occupying Power in the 1954 Hague Convention and the lack of sufficient state practice to prove the existence of an international customary norm, ${ }^{108}$ a functional, object and purpose oriented

100. Gavin Lucas, Destruction and the Rhetoric of Excavation, 34 NORWEGIAN ARCHAEOLOGY REV. 35, 35 (2001).

101. UNESCO, Records of the General Conference, Ninth Session, New Delhi 1956: Resolutions, at 44, 32 (1957), quoted in JIRI TOMAN, THE PROTECTION OF CULTURAL PROPERTY IN THE EVENT OF ARMED CONFLICT 87 (1996).

102. 1999 Second Protocol, supra note 14, art. 9(1)(b).

103. O'KEEFE, supra note 98 , at $138-40$.

104. Id. at 139.

105. ARAI-TAKAHASHI, supra note 73, at 252.

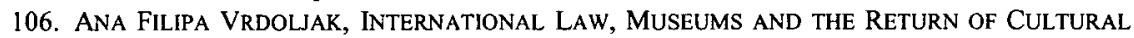
OBJECTS 149 (2006).

107. UNESCO, Gen. Conference, Jerusalem and the Implementation of Resolution 3.427 Adopted by the Eighteenth Session of the General Conference, § II, U.N. Doc. 19 C/113 Annex (Oct. 29, 1975), available at http://unesdoc.unesco.org/images/0002/000228/022874eb.pdf. See also CLARE WELLS, THE UN, UNESCO AND THE POLITICS OF KNOWLEDGE 3 (1987).

108. O'KEEFE, supra note 98, at 139. 
interpretation of the occupier's authority suggests that a prohibition can, and should be, read into Article 5 of the 1954 Hague Convention. ${ }^{109}$

O'Keefe also highlights that competent national authorities in occupied territories should still have the province to regulate excavations. ${ }^{110}$ As laid out in Article 9(2) of the 1999 Second Protocol: "Any archaeological excavation of, alteration to, or change of use of, cultural property in occupied territory shall, unless circumstances do not permit, be carried out in close co-operation with the competent national authorities of the occupied territory."111 One delegate expressed strong opposition to the "unless circumstances do not permit" qualification, since in some occupied territories the activities of the local institutions are curtailed or even subjected to closure. ${ }^{112}$ Indeed this is the case of the Palestinian Department of Antiquities and Cultural Heritage whose ability to conduct excavations has been a priori curtailed by the Israeli authorities.

Israeli institutions, in turn, have relied on this reality to justify excavations without cooperation with the national authorities of the legitimate Palestinian sovereign, including its contentious archaeological activities in the Old City of Jerusalem, and the Mosque of Ibrahim at the Cave of the Patriarchs in Hebron, part of which was converted into a synagogue after Israel occupied the West Bank. ${ }^{113}$ Israel's widespread practice of excavations is based on the view that international law does not forbid excavations in occupied territory. ${ }^{114}$ The details of Israel's excavations remain largely unknown to the Palestinian authorities, and it is clear that its practice unmistakably exceeds the limits set out by the international law of occupation, which generally prohibits most types of archaeological activity, and in particular, excavations that can be expected to result in the destruction of cultural property. ${ }^{115}$

In addition to the package of preventive mechanisms, the 1954 Hague Convention provides a set of remedies including criminal liability and restitution. The definition and institutionalization of the consequence of criminal prosecution

109. The occupier's obligation to maintain normal life in the occupied territory entails, in practice, the conservation of the cultural, political and social fabric of life of the occupied population, as well as ensuring the continuation of their organic development within their cultural, political and social ecosystem. O'KEEFE, supra note 98, at 139.

110. He infers that the provision is precautionary, premised on the idea that the only way to safeguard it is to ban all excavations for the duration of the occupation. Id. at 262 .

111. 1999 Second Protocol, supra note 14, art. 9(2).

112. The delegate is not named. O'KEEFE, supra note 98, at 263.

113. Id. at 140,262 . The measure was declared null and avoid by the U.N. General Assembly in 1975. G.A. Res. 3525 (XXX) ๆ D(1), U.N. Doc. A/RES/3525(XXX) (Dec. 15, 1975).

114. Joanna Overdiran, Plunder, Destruction, and despoliation: An analysis of ISRAEL'S VIOLATION OF THE INTERNATIONAL LAW OF CULTURAL PROPERTY IN THE OCCUPIED WEST BANK AND GaZA STRIP 17 (1997). Professor H. Reinink, Commissioner-General for Cultural Property accredited to Israel, was of the view "that excavations were not prohibited by the [1954 Convention] but only by the UNESCO Recommendation ... [that] was not legally binding." Id.

115. Sliman, supra note 49 , at $355-56$. 
for offences against cultural property is rooted in the international legal order. ${ }^{116}$ While the 1954 Hague Convention provides for individual criminal responsibility in case of certain breaches, the effectiveness of the provision was undermined by the lack of a list of specific offenses that could give rise to criminal sanctions, later enunciated in Article 15 of the 1999 Second Protocol as part of five "serious violations:" the first three corresponding to grave breaches of the Geneva Conventions and Additional Protocol I of $1977,{ }^{117}$ the fourth and fifth considered serious violations of the 1954 Hague Convention and the 1999 Second Protocol. ${ }^{118}$ The Statute of the International Criminal Court ${ }^{119}$ and the International Criminal Tribunal for the Former Yugoslavia ${ }^{120}$ recognized the fourth and fifth acts as "war crimes." The two "serious violations" of relevance to occupied territory, which are subject to mandatory universal jurisdiction within the meaning of Article 16(1) of the 1999 Second Protocol, are "extensive destruction or appropriation of cultural property," and "theft, pillage or misappropriation of, or acts of vandalism directed against, cultural property," resonating the provisions on property protection in the 1907 Hague Regulations. ${ }^{121}$

There are limits on the ability of international criminal law to ensure the protection of cultural property. Similarly, under the principle of universal jurisdiction for war crimes applicable to these offenses, states are permitted to enact universal jurisdiction laws, but are neither compelled, ${ }^{122}$ nor regulated, in the manner in which they legislate to pursue perpetrators. ${ }^{123}$ Nevertheless,

116. ARAI-TAKAHASHI, supra note 73, at 254 (noting that The Report of the Commission on Responsibility established this as early as 1919 (citing COMM'N ON RESPONSIBILITY OF THE AUTHORS

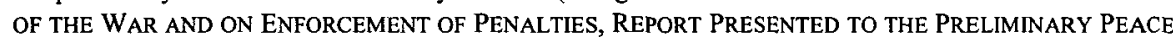
CONFERENCE (1919), reprinted in 14 AM. J. INT'L L. 95, 115 (Jan.-Apr. 1920)).

117. In particular: (1) "[M]aking cultural property under enhanced protection the object of attack;" (2) "using cultural property under enhanced protection or its immediate surroundings in support of military action;" (3) "extensive destruction or appropriation of cultural property protected under the Convention and [Protocol II]." 1999 Second Protocol, supra note 14, art. 15.

118. In particular: (4) "making cultural property protected under the Convention ... the object of attack;" (5) "theft, pillage or misappropriation of, or acts of violence directed against, cultural property protected under the Convention." 1999 Second Protocol, supra note 14, art. 15.

119. See Rome Statute of the International Criminal Court, art. $8(2)(\mathrm{b})(\mathrm{ix})$, U.N. Doc. A/CONF.183/9, July 17, 1998, 2187 U.N.T.S. 90 (showing that offenses of destroying or willfully damaging cultural property are covered by one of the specific offences relating to conduct of hostilities, namely, of attacks intentionally directed against immovable cultural property as a specific category of war crimes).

120. Updated statute of the International Criminal Tribunal for the former Yugoslavia, art. 8(d), adopted by S.C. Res. 827, U.N. Doc. S/RES/827 (May 25, 1993), available at http://www.icty.org/x/file /Legal\%20Library/Statute/statute_sept09_en.pdf.

121. 1999 Second Protocol, supra note 14, arts. 15-16.

122. Id. art. 16(2)(b). See also Jean-Marie Henckaerts, New Rules for the Protection of Cultural Property in Armed Conflict: The Significance of the Second Protocol to the 1954 Hague Convention for the Protection of Cultural Property in the Event of Armed Conflict, in PROTECTION OF CULTURAL PROPERTY IN THE EVENT OF ARMED CONFLICT 51-52 (2000), available at http://www.icrc.org/eng/asset s/files/other/report-icrc_002_0805.pdf.

123. The United States succeeded in its application for an exception to universal jurisdiction for nationals not party to the 1999 Second Protocol. Henckaerts, supra note 122, at 51. 
international criminal law has a credible track record of prosecutions for violations of the cultural property laws of armed conflict. ${ }^{124}$ In some cases, offences against cultural property can amount to crimes against humanity, in so far as these acts are part of a broader set of facts on the widespread or systematic persecution of a civilian population. ${ }^{125}$ While the International Criminal Tribunal for Yugoslavia has been successful in prosecuting and punishing crimes related to cultural property, restitution and restoration of cultural property remain deficient.

Restitution is governed by Article 1(3) of the First Protocol of the 1954 Hague Convention, to which states parties must return cultural property that has been removed from the occupied territory at the close of hostilities. Israel is a High Contracting Party. Consequently, "[i]f the continued hostilities have no bearing on this issue, artifacts should be returned irrespective of the ongoing hostilities."126 The solution adopted by Article 1 of the Protocol is administrative and does not deal with questions of ownership, in that objects taken from an occupied territory are to be returned to its competent authorities, which are expected to decide on questions of ownership. ${ }^{127}$ An important precedent, amongst others, is the 1993 handover to Egypt of all archaeological findings from Israel's excavations in Sinai during its occupation from 1967 to $1983 .{ }^{128}$ All items were returned in 1994. The duty to effect restitution is "categorical," but arguably only applies "where it is the territory of another Contracting Party that is occupied." 29 Egypt is a High Contracting Party to the 1954 Hague Convention, and the 1993 Agreement between Israel and Egypt concisely provided: "all artifacts and finds from Sinai will be returned to Egypt within the next two years ... . Those artifacts which have been processed and documented, will be returned to Egypt within the next two months."

A Palestinian ratification of the 1954 Hague Convention and its Protocol would invoke the restitution provisions of the treaty for objects removed from the Palestinian territory during the continuing occupation. The question of retroactive effect would be open for examination based on the potential customary character of the 1954 Hague Convention and its Protocol, and is considered a debatable issue in permanent status negotiations. ${ }^{131}$ A strategy for restitution that aims to effectively correct the wrongs committed during the occupation of Palestinian territory needs to ensure the return of cultural property to its rightful place and

124. See Hirad Abtahi, The Protection of Cultural Property in Times of Armed Conflict: The Practice of the International Criminal Tribunal for the Former Yugoslavia, 14 HARV. HUM. RTS. J. 1, 30-31 (2001).

125. Id. at $25-28$.

126. Talia Einhom, Restitution of Archaeological Artifacts: The Arab-Israeli Aspect, 5 INT'L J. Cultural Prop. 133, 143-44 (1996).

127. Id. at 141 .

128. Id. at 142 .

129. Id. at $138-39$.

130. Id. at 142 .

131. Fahel, supra note 9. 
owner, and this question is part of bilateral negotiations. ${ }^{132}$ In a similar vein, U.N. General Assembly Resolution 3391 (XXX) on the Restitution of Works of Art to Countries Victims of Expropriation highlights the special obligation imposed on states that had access to valuable objects "as a result of their rule over or occupation of a foreign territory." 133

An illustrative example of Israel's illegal removal of artifacts from the Palestinian territory is the case of the Dead Sea Scrolls, removed from the Palestine Archaeological Museum in East Jerusalem in 1967, where they were held on display since their discovery in Qumran, a village located in the West Bank on the northwest coast of the Dead Sea, in a series of excavations between 1947 and $1956{ }^{134}$ At present, the Scrolls are listed as part of the Inventory of Cultural and Natural Heritage Sites of Potential Outstanding Universal Value in Palestine, compiled jointly by UNESCO and Palestinian institutions. ${ }^{135}$ In June 2009 , the Scrolls were exhibited by the Israel Antiquities Authority at the Royal Ontario Museum in Toronto, Canada. Despite written protests by the Palestinian Minister of Tourism and Antiquities to the Royal Ontario Museum and the Canadian government, the exhibit ran until January 2010 in violation of Israel, Canada and the Museum's obligations under the UNESCO framework. ${ }^{136}$ Jordan, which occupied the West Bank in the period of the excavations that led to the Scrolls' discovery, also sent a diplomatic communication near the end of the Royal Ontario Museum exhibit requesting Canada to seize the Scrolls. ${ }^{137}$

Despite claims in the Canadian media that "the application to the scrolls of the 1954 Hague Convention is not clear-cut," the rules are in fact

132. Id.

133. G.A. Res. 3391 (XXX), ๆ 2, U.N. Doc. A/RES/3391 (Nov. 19, 1975).

134. Canadians for Justice and PEACE In the Middle EAst, FaCtSheEt: Legal Violations WITH THE ROM'S DEAD SEA SCROLLS EXHIBIT (2009), available at http://www.cjpmo.org/DisplayDoc ument.aspx? DocumentID=409.

135. The listing was done in 2005. Fact Sheet on the Illegal Removal of the Dead Sea Scrolls from Occupied Palestinian Territory (on file with authors). See also, Elias Sanbar, Protection of Artifacts Removed from the Occupied Palestinian Territory, ALJAZEERRA TRANSPARENCY UNIT (Apr. 15, 2009), available at http://thepalestinepapers.com/en/document/4524.

136. Palestinians Call on Canada to Cancel Scroll Exhibition, Dawn.com (Apr. 13, 2009), http://archives.dawn.com/archives/92452. The Royal Ontario Museum's obligations are premised on its membership in the Canadian Museums Association, which is committed to the ethical guidelines set out by the International Council of Museums, namely Section 2. See INTERNATIONAL COUNCIL OF MUSEUMS, ICOM CODE OF ETHICS FOR MUSEUMS 3-6 (2013), available at http://icom.museum/filead $\mathrm{min} /$ user_upload/pdf/Codes/code_ethics2013_eng.pdf. The Museum must also ensure that at a minimum it does not offend the criminal standard set out in Section 36.1(2) of Canada's Cultural Export and Import Act, which provides that "no person shall knowingly export or otherwise remove cultural property ... from an occupied territory of a State Party to the Second Protocol." Cultural Property Export and Import Act, R.S.C. 1985, c. C-51, available at http://laws-lois.justice.gc.ca/eng/acts/C-51/pa ge-11.html.

137. Michael Valpy, Scroll Exhibit Closes Amid Controversy, The GLOBE AND MAIL (Jan. 4, 2010), http://www.theglobeandmail.com/news/national/scroll-exhibit-closes-amid-controversy/article14 17846/. 
straightforward. ${ }^{138}$ Canada, who is a signatory to the 1954 Hague Convention and its protocols, was under an obligation to "take into custody cultural property imported into its territory either directly or indirectly from any occupied territory" and to return it to the local authorities in the occupied territory. ${ }^{139}$ The Canadian government based its decision to refuse Palestinian requests to halt the exhibition on the fact inter alia that Palestine was not a State Party to the 1954 Hague Convention and its Protocols. Palestine's UNESCO membership and accession to the Convention provide it with additional clout to claim rights and demand compliance by other states in relation to the Scrolls, as well as other artifacts removed from its territory during occupation. Sections of the Scrolls have also been recently exhibited in the U.S., ${ }^{140}$ which has accepted the customary nature of the 1954 Hague Convention and its First Protocol. ${ }^{141}$ Should Palestine ratify the 1954 Hague Convention and its first Protocol, it could consider filing a case before U.S. courts to request the property's seizure. ${ }^{142}$

\section{ThE ILLICIT TRADE IN ANTIQUITIES}

The illegal antiquities market is comparable to other major international criminal enterprises such as drugs or arms smuggling, with one major exception; antiquities pass through a series of portals where they are transformed from illegal to legal. ${ }^{143}$ In other words, they are laundered. ${ }^{144}$ There are insufficient studies on the global trade in illicit antiquities, with the first book on the subject not appearing until $1973,{ }^{145}$ with no mention of Palestine. A more recent work with a number of international contributions similarly does not examine the illicit trade in Palestine. ${ }^{146}$ In fact, there is a mere handful of studies on the illicit trade in Palestinian antiquities, despite figures from Palestinian sources attesting to

138. $I d$.

139. Protocol to the Convention for the Protection of Cultural Property in the Event of Armed Conflict art. 1, opened for signature May 14, 1954, 249 U.N.T.S. 358.

140. John R. Quain, Dead Sea Scrolls Get New Life, FoX NEws (Feb. 8, 2012), http://www.fox news.com/scitech/2012/02/08/dead-sea-scrolls-get-new-life/.

141. See U.S. NAVAL HANDBOOK, supra note 71, at 299-305.

142. See Howard N. Spiegler \& Lawrence M. Kaye, American Litigation to Recover Cultural Property: Obstacles, Options, and a Proposal, in TRADE IN ILLICIT ANTIQUITIES: THE DESTRUCTION OF THE WORLD'S ARCHAEOLOGICAL HERITAGE 121-32 (Neil Brodie, Jennifer Doole \& Colin Renfrew eds., 2001) (discussing litigation before the U.S. courts in relation to the retum of cultural property).

143. Morag M. Kersel, From the Ground to the Buyer: A Market Analysis of the Trade in Illegal Antiquities, in ARCHAEOlOGY, CUlTURAL HeRITAGE, AND THE ANTIQUITIES TRADE 188-89 (Morag M. Kersel, Christina Luke \& Kathryn Walker Tubb eds., 2006) (hereinafter Kersel, From the Ground to the Buyer].

144. Id. at 189.

145. KARL E. MEYER, The PLUNDERED PAST 132 (1973). Meyer notes in his text that this absence of research is difficult to understand given that the plundering of tombs and temples is "assuredly the [world's] second-oldest profession." Id.

146. See generally TRADE IN ILLICIT ANTIQUITIES: THE DESTRUCTION OF THE WorLd'S ARCHAEOLOGICAL HERTtaGe v, vi (Neil Brodie, Jennifer Doole \& Colin Renfrew eds., 2001) (making no mention of Palestine at any point in the more modern text). 
hundreds of thousands of objects being illegally exported from the occupied Palestinian territory every year. ${ }^{147}$ Yahya estimates:

$[\mathrm{H}]$ istoric Palestine (Israel, the West Bank \& Gaza Strip) has a total of more than 35,000 large and small archaeological sites and features (caves, ruins, tells, sanctuaries, quarries, towers, churches, mosques, etc.) from all historic and prehistoric periods. The West Bank alone contains about a third of these sites and features $(12,217) \ldots$. . Many of these sites have been destroyed, particularly since the occupation of the West Bank by Israel in 1967. The exact number of sites robbed in the occupied territories since then is unknown, but it is estimated to be in the thousands. ${ }^{148}$

The primary international legal instrument governing the illicit trade in antiquities is the 1970 UNESCO Convention on the Means of Prohibiting and Preventing the Illicit Import, Export and Transfer of Ownership of Cultural Property ("1970 UNESCO Convention"). ${ }^{149}$ It is an unsatisfactory instrument, with a number of agreed shortcomings. Curiously, commentators have noted that the majority of its provisions were never designed to be implemented. Bator writes: "only a small fraction of the Convention was intended to have serious operative consequences; the rest has only rhetorical existence." 150

The scope of the 1970 UNESCO Convention is limited in the chapeau of Article 1 to cultural property, which is "specifically designated by each State as being of importance for archaeology, prehistory, history, literature, art or science." As a result, "unlawfully excavated cultural objects are not covered by the 1970 [UNESCO] Convention which only provides for the restitution of inventoried cultural objects stolen from a museum or similar institution."152 In many states, clandestine excavations are the largest contributor to illicit trade. ${ }^{153}$ More generally, it is considered that the instrument is undermined by textual weaknesses, and the fact that many art-importing states have not ratified it. ${ }^{154}$

147. Yahya, supra note 59.

148. Id.

149. 1970 UNESCO Convention, supra note 15.

150. Paul M. Bator, The International Trade IN ART 94-95 (Univ. of Chi. Press 1983) (1982).

151. 1970 UNESCO Convention, supra note 15 , art. 1.

152. UNIDROIT Secretariat, UNIDROIT Convention on Stolen or Illegally Exported Cultural Objects: Explanatory Report, UNIF. L. REV. 476, 504 (2001) [hereinafter UNIDROIT Explanatory Report], availahle at http://www.unidroit.org/english/conventions/1995culturalproperty/1995culturalpr operty-explanatoryreport-e.pdf.

153. Ian M. Goldrich, Comment, Balancing the Need for Repatriation of Illegally Removed Cultural Property with the Interests of Bona Fide Purchasers: Applying the UNIDROIT Convention to the Case of the Gold Phiale, 23 FORDHAM INT'L L.J. 118, 138 n.107 (1999) (giving the example of Italy in this regard).

154. Nina R. Lenzner, Comment, The Illicit International Trade in Cultural Property: Does the UNIDROIT Convention Provide an Effective Remedy for the Shortcomings of the UNESCO Convention?, 15 U. PA. J. INT'L BUS. L. 469, 478-79 (1994). Although Australia, Canada and the 
Israel, in common with other "transit States" has not ratified the 1970 UNESCO Convention. ${ }^{155}$

In an effort to address the recognized shortcomings, UNESCO requested the drafting of a supplementary private international law convention by the International Institute for the Unification of Private Law ("UNIDROIT"), the UNIDROIT Convention on Stolen or Illegally Exported Cultural Objects ("UNIDROIT 1995"). It was opened for signature in 1995. ${ }^{156}$ As UNESCO had asked UNIDROIT to focus on the private law elements of the implementation of the 1970 UNESCO Convention, both instruments are considered complementary or "fully compatible.""157 UNIDROIT 1995 covers two categories of cultural property, stolen and illegally exported, with differing rules regarding each. Importantly, UNIDROIT 1995 has no retroactive effect, so that it does not allow for the restitution of cultural objects stolen or illegally exported before its entry into force. ${ }^{158}$

The private international law approach undertaken in UNIDROIT 1995 endows claimants - who may be private individuals as well as states-with certain rights, permitting a cause of action to be brought in the location country of the object being sought. ${ }^{159}$ Thus under Article $8(1)$, jurisdiction lies only with "the courts or other competent authorities of the Contracting State where the cultural object is located." 160 Essentially, it "puts the courts . . . in charge of resolving disputes over cultural property." 161 While theft is a sufficient ground in itself to claim restitution under UNIDROIT $1995,{ }^{162}$ illegal export is not a sufficient ground to obtain a court order for an object's return. ${ }^{163}$

Article 5(1) allows contracting states to request the return of a cultural object illegally removed from its territory, provided the requesting state and the state addressed are parties to UNIDROIT 1995. ${ }^{164}$ Article 1(b) defines "illegally exported" as "removed from the territory of a Contracting State contrary to its law regulating the export of cultural objects for the purpose of protecting its cultural heritage," meaning the requesting state must have specific regulations governing

United States are signatories in terms of the text, Lenzner notes that many of the 1970 Convention's provisions amount to "mere rhetoric" with no real requirements imposed on signatories. $I d$. at 479-80.

155. See States Parties: Ratification Status, UNESCO.oRg (Sept. 19, 2012), http://whc.unesco.org /en/statesparties/ (showing the list of nations that have ratified the Convention).

156. 1995 UNIDROIT Convention, supra note 16.

157. UNIDROIT Explanatory Report, supra note 152, at 480.

158. Id. at 490 (noting that the Preamble uses the phrase "in the future" in this regard).

159. Lenzner, supra note 154 , at 493-94.

160. 1995 UNIDROIT Convention, supra note 16, art. 8(1).

161. Lenzner, supra note 154 , at 494.

162. 1995 UNIDROIT Convention, supra note 16, art.1 (stating that claims must have an "international character" possessed by definition for illegally exported objects but not necessarily for stolen objects). See also UNIDROIT Explanatory Report, supra note 152, at 494.

163. UNIDROIT Explanatory Report, supra note 152, at 526.

164. Id. 
the protection of its cultural objects. ${ }^{165}$ Article 5(3) sets out the interests protected which define the types of objects covered. It reads:

The court or other competent authority of the State addressed shall order the return of an illegally exported cultural object if the requesting State establishes that the removal of the object from its territory significantly impairs one or more of the following interests:

(a) the physical preservation of the object or of its context;

(b) the integrity of a complex object;

(c) the preservation of information of, for example, a scientific or historical character;

(d) the traditional or ritual use of the object by a tribal or indigenous community, or establishes that the object is of significant cultural importance for the requesting State. ${ }^{166}$

According to the Explanatory Report, the "physical preservation of the object or of its context" encompasses the protection of archaeological sites from pillage or illegal excavations, while "the preservation of information, of, for example, a scientific or historical character" envisions clandestine excavations. ${ }^{167}$ A general provision following the fourth subcategory is included for objects of "significant cultural importance," considered a restrictive term to be narrowly interpreted. ${ }^{168}$ Under Article 5(4), the requesting state must supply "all relevant information of a legal (in particular, any export regulations that have been infringed) or cultural nature, such as expert evidence to determine the extent of the damage" to the interests listed in Article 5(3). ${ }^{169}$

Article 5 is a reflection of the deliberations on UNIDROIT 1995 that repeatedly expressed concern with the pillaging of archaeological sites, a practice that fell outside the remit of the 1970 UNESCO Convention. Subparagraph 4 of the Preamble reads: "deeply concerned . . . in particular [by] the pillage of archaeological sites and the resulting loss of irreplaceable archaeological, historical and scientific information;" the definitions in Article 2 reference "objects which are of importance for archaeology;" and Article 3(2) uses the words "cultural object which has been unlawfully excavated or lawfully excavated but unlawfully retained."170 These perceived deviations have spurred some debate over whether such objects should be considered stolen or illegally exported. Subsequently it was decided to include a special provision where the general conditions for bringing claims for return, under Article 5(3)(a)-(c), were specifically formulated to include excavated objects. $^{171}$

165. Id.

166. 1995 UNIDROIT Convention, supra note 16, art. 5(3).

167. UNIDROIT Explanatory Report, supra note 152, at 528-30 (discussing Article 5(3)(a)-(d) of the 1995 UNIDROIT Convention).

168. Id.

169. Id. at 532 .

170. Id. at 504 (quoting 1995 UNIDROIT Convention, supra note 16).

171. Id. 
Article 11 sets out the procedure for signing, ratifying, approving or acceding to the Convention. All States may become contracting parties to UNIDROIT 1995 whether or not they are members of UNIDROIT, ${ }^{172}$ subject to the deposit of a formal instrument to that effect with the Italian Government as its depositary and thirty-three signatories at present. ${ }^{173}$

UNIDROIT 1995 balances "the interests of dispossessed owners and bona fide purchasers by requiring restitution of the stolen object and compensation to purchasers when they have exercised the necessary due diligence." ${ }^{174}$ It reconciles tensions "between market and source nations, and between the civil and common law countries by protecting ... the rights of the original owner and of the bona fide purchaser."175 Fundamentally, however, it significantly expands the rights of contracting parties "seeking the return of illegally exported [cultural] property by providing ... private litigation rights without ... government intercession." 176

In the case of Palestine, the pathway of the illicit trade is broadly identifiable. Initially, local people, or subsistence diggers, "are usually responsible for the looting of archaeological sites." 177 "They sell to middlemen, who ... resell to the antiquities dealers at a [high] mark-up;" it is these "middlemen who retain the majority of the profits," with the original looter usually receiving less than one percent of the retail value. ${ }^{178}$ Palestinian involvement in the looting stems from the alienation of the population from its own cultural heritage. Sites excavated by Israeli or foreign archaeologists are invariably shipped out of the country and exhibited in museums to which Palestinians have no access. ${ }^{179}$ More pragmatically, looting grows in line with unemployment, with looting increasing 300 percent following the outbreak of the al-Aqsa intifada in 2000 , preventing Palestinians from seeking employment in Israel. ${ }^{180}$

Israel is one of the few states with a legally sanctioned antiquities market. According to Kersel, "Israel is an excellent example of a geographically advantaged state due to its proximity to the Palestinian Authority ("PA"), where most of the looting in this region occurs." where "the conversion from illegal to legal takes place," and once an export license is attained "the material can be successfully negotiated through customs" openly and legally, entering the market as a legitimate antiquity. ${ }^{182}$ Israel's 1978 national

172. Id. at 552.

173. 1995 UNIDROIT Convention, supra note 16.

174. Claudia Fox, Note and Comment, The UNIDROIT Convention on Stolen or Illegally Exported Cultural Objects: An Answer to the World Problem of Illicit Trade in Cultural Property, 9 AM. U. J. INT'L L. \& POL'Y, 225, 257 (1993).

175. Id. at 266 .

176. Id. at 257.

177. Kersel, From the Ground to the Buyer, supra note 143, at 190.

178. Id.

179. Yahya, supra note 59.

180. Id.

181. Kersel, From the Ground to the Buyer, supra note 143, at 191.

182. Id. at 193 . 
patrimony law vests ownership of archaeological material in the state, meaning it is legal to buy and sell artifacts from pre-1978 collections, with a consequent system of legally-sanctioned dealers in antiquities who may request export permits issued by the Israel Antiquities Authority ("IAA"). ${ }^{183}$ As highlighted, a law on national patrimony for Palestine is being drafted by the PA, with the issue of the legal sale of antiquities still to be adjudged, which means that at present cultural heritage protection in Palestine is still governed by the Jordanian Law of Antiquities. $^{184}$

Documentation and reports confirm that a significant amount of "material [on] sale in the legally sanctioned shops in Israel" originates in looted sites in Palestine. ${ }^{185}$ It is possible for dealers "to sell looted material by exchanging the registry numbers of materials already sold with those of a similar description," which have just appeared on the market. ${ }^{186}$ An antiquity receives an official registry number. For instance, if a tourist buys the antiquity from a legally sanctioned dealer, they are required to obtain an export license from the IAA. As this is not always the case, there is no comprehensive official record of these sales, and the same registry number can be used again. ${ }^{187}$ The chronic underfunding of the PA Department of Antiquities, and to a lesser extent the IAA, means a low level of priority is given to such issues in light of the current political situation, allowing Israel's unique legal market to provide a "perfect setting for looting and illegal excavation." 188 Kersel concludes:

Artefacts routinely ... enter a process of laundering, and then are sold as "legally" exported from licensed dealers in Israel. The Israeli legal venue that allows the sale of illegally-excavated artefacts provides an impetus for looting. Artefacts, many from the West Bank and Gaza, routinely make their way into the legitimate marketplace through a system of laundering and the reuse of inventory numbers. ${ }^{189}$

A further difficulty is underlined by the belief that the SOA in the occupied Palestinian territory is effectively marking sites for looters, due to the insufficient funding provided for the maintenance of excavations sites. Greenberg and Keinan note, for example, how he "uncovered a beautiful mosaic in a Byzantine church, but after he left thieves came and removed the entire mosaic." ${ }^{190}$ Or as Rjoob writes on Khirbet al Qasir, in the wilderness of Hebron: "The SOA excavated the site without any justification, subsequently transferring its artifacts to unknown whereabouts and leaving the site without the minimum means of protection and to

183. Id. at 195.

184. Id.

185. Id.

186. Id. at $195-96$.

187. Id. at 196.

188. Id. at 197-98.

189. Kersel, The Trade in Palestinian Antiquities, supra note 18, at 30.

190. Rjoob, supra note 10 (quoting Meron Rapoport, supra note 43). 
the mercy of antiquities robbers." ${ }^{\prime 19}$ In some cases, the looters are the Palestinian laborers employed on the sites during the "salvage excavation," who subsequently return to plunder the remains, which then make their way to the legal antiquities market in Israel. An account from the excavator at El Qom is illustrative:

$[W]$ e did a little investigation of the Iron Age site and we determined that Khirbet El-Qôm was certainly biblical Maqqidah, a very important border fortress. After we left the site there was no control and the villagers must have resumed digging, because the market a few years latei was flooded by hundreds of Idomaean ostraca inscriptions on pottery, ink inscriptions from the Persian and early Hellenistic periods. Basically our excavation must have trained the villagers as future looters. ${ }^{192}$

The practices of locals are rooted in the belief that archaeologists are themselves profiting from that which they excavate, with "the enforcement of protectionist laws as redirection of local wealth to foreigners." 193 Kersel et al., in their anthropological study consisting of interviews, concluded that many locals "come to view archaeologists as looters themselves, but 'looters who operate above the law." 194 Communication between archaeologists and locals is poor, with the effect that "locals cannot help but wonder if artifacts recovered in scientific excavations are bound for the antiquities market" in Israel. ${ }^{195}$

The UNESCO and UNIDROIT framework is imperfect, with the former having a severely restricted reach and the latter a low level of ratification, meaning only the courts of a small number of states are actionable should Palestinian antiquities from illegally-excavated sites end up outside Palestine's borders. Some of the market nations, including the U.K., U.S., and Canada, have not ratified UNIDROIT 1995, although it has been ratified by Switzerland. ${ }^{196}$ Yet, the Convention ought to be seen not as an end in itself, but rather as a "step in the continuing war against the illicit trade" in antiquities. ${ }^{197}$ There is no question that the best means of avoiding difficult "private lawsuits is to utilize local and

191. Id. Rjoob also quotes an SOA employee who participated in the excavation: "Our excavations revealed a well-preserved Roman-Byzantine settlement, built with well-dressed stones and paved with splendored colored and monochrome mosaics. However, by the end of the excavations, all artifacts were transferred to unknown storerooms in Jerusalem and the site has been abandoned and left without any protection measures. Since the end of excavations, I have not returned to the site. It might be badly deteriorated." Id.

192. Morag M. Kersel, Christina Luke \& Christopher H. Roosevelt, Valuing the Past: Perception of Archaeological Practice in Lydia and the Levant, 8 J. SOC. ARCHAEOLOGY 298, 310 (2008) (quoting a personal communication with William Dever).

193. Id. at 314.

194. Id. (quoting Morag M. Kersel, License to Sell: The Legal Trade of Antiquities in Israel (2006) (unpublished Ph.D. dissertation, Department of Archaeology, University of Cambridge)).

195. Id. at 315.

196. 1995 UNIDROIT Convention, supra note 16.

197. Spiegler \& Kaye, supra note 142 , at 130. 
international law enforcement authorities ... to enforce local criminal statutes and international conventions." 198

A related issue is the need for Palestine to establish its own legal trade in antiquities. According to Spiegler and Kaye, "calls for the licit market come from those who just do not want the art of source nations to continue to be maintained by those nations, which is a policy that in our view fails on both sovereign and equitable grounds." 199 The Jordanian experience is illustrative, whereby a legal trade for licensed dealers existed until 1976, overseen by the Department of Antiquities. The abolition of this trade saw "a surge in illicit excavations and pillaging ... with the creation of a brisk black market." 200 Bisheh of the Jordanian National Museum sees equally convincing arguments for prohibition and legalization under strict measures of control, although ultimately would vote against a legal trade. ${ }^{201}$

\section{Underwater Cultural Heritage}

Protection of underwater cultural heritage can further efforts to assert control over Palestine's waters, off the coast of the Gaza Strip, where Israel has been imposing a prolonged naval blockade, which prevents Palestinians from having any access to most parts of their territorial waters. ${ }^{202}$ "On 8 December 2011, Palestine deposited with the [UNESCO] Director-General its instrument of ratification of the [2001] Convention on the Protection of the Underwater Cultural Heritage,"203 ("Underwater Heritage Convention") which entered into force on 8 March 2012. ${ }^{204}$ The Underwater Heritage Convention was drafted in response to the recent expansion of the discipline of underwater archaeology, which has extended its sphere from relatively shallow coastal waters to the deep seabed with the rapid development of technology. ${ }^{205}$ As expressed by the Canadian delegation

198. Id. at 125 .

199. Id. at 130 .

200. Ghazi Bisheh, One Damn Illicit Excavation Afier Another: The Destruction of the Archaeological Heritage of Jordan, in TRADE IN ILLICIT ANTIQUITIES: THE DESTRUCTION OF THE WORLD'S ARCHAEOLOGICAL HERITAGE 115 (Neil Brodie, Jennifer Doole \& Colin Renfrew eds., 2001).

201. Id. at 118 .

202. An analysis of the blockade is beyond the scope of this paper. At present Gaza does not control its territorial waters and approximately " 85 per cent of its fishing waters are totally or partially inaccessible due to Israeli military measures," according to a U.N. Human Rights Council panel report. The experts concluded that the blockade of Gaza continues to violate international law. See News Release, U.N. Human Rights Office of the High Commissioner, How Can Israel's blockade of Gaza be Legal? - U.N. Independent Experts on the "Palmer Report," UN.ORG (Sept. 13, 2011), http://unispal.un.org/UNISPAL.NSF/0/D805C73314EFC9E78525790A0055784E.

203. UNESCO, Ratification by Palestine of the Convention on the Protection of the Underwater Cultural Heritage, UNESCO.oRG (Jan. 16, 2012), http://portal.unesco.org/en/ev.php-URL_ID=48774\& URL_DO=DO_TOPIC\&URL_SECTION=201.html.

204. Id.

205. Craig Forrest, A New International Regime for the Protection of Underwater Cultural Heritage, 51 INT'L \& COMP. L. Q. 511 , 512 (2002). Technological advances have made 98 percent of the seabed accessible. See Frederik SOREIDE, SHIPS From the DEPTHS: DEEPWATER ARCHAEOloGY 4 (2001). 
at the drafting conference, it is apparent that "the main thrust of the proposed convention should be to deal with treasure hunters or dive expeditions which focus on [underwater cultural heritage]."206 The definition of underwater cultural heritage in Article 1(a) of the Underwater Heritage Convention is "all traces of human existence having a cultural, historical or archaeological character which have been partially or totally under water, periodically or continuously, for at least 100 years." ${ }^{207}$ The Underwater Heritage Convention's objective is to preserve underwater cultural heritage for the benefit of humanity through cooperation between state parties, without the determination of ownership rights.

The geographical scope of the Underwater Heritage Convention, or its jurisdictional reach, is threefold, based on the differing zones of a State Party's waters. The overall aim is in situ protection, but "where it is concluded that recovery is appropriate, to ensure that it is undertaken in accordance with the terms" set out in the Annex to the Underwater Heritage Convention. ${ }^{208}$ First, under Article $7(1)$, a State Party has the "exclusive right to regulate and authorize activities directed at underwater cultural heritage in their internal waters, archipelagic waters and territorial sea." 209 These terms are defined by the U.N. Convention on the Law of the Sea 1982 ("UNCLOS"), ${ }^{210}$ which requires that any interpretation of the Underwater Heritage Convention be consistent with its provisions. Articles 2 and 3 of UNCLOS hold that the territorial sea, a belt of coastal waters extending at most twelve nautical miles from the baseline of a coastal state, is regarded as part of the state's sovereign territory.

Secondly, under Article 8 of the Underwater Heritage Convention, the State Party may "regulate and authorize activities directed at underwater cultural heritage within their contiguous zone."211 The contiguous zone is defined in Article 33 of UNCLOS as not more than twenty-four nautical miles, an area in which competence is exercised for special purposes. ${ }^{212}$ Although "[a] state does not have to claim a contiguous zone . . . about one-third of coastal states do."213 For example, the Netherlands recently established a contiguous zone with the aim inter alia of preventing the infringement of rights governing objects of an archaeological or historic character. ${ }^{214}$ The practical result was the extension of the geographical scope of its relevant domestic legislation to prohibit the

206. Forrest, supra note 205 , at $531 \mathrm{n} .87$.

207. Underwater Heritage Convention, supra note 17, art. 1(a).

208. Sarah Dromgoole, 2001 UNESCO Convention on the Protection of the Underwater Cultural Heritage, 18 INT'L J. MARINE \& COASTAL L. 58, 76 (2003).

209. Underwater Heritage Convention, supra note 17 , art. $7(1)$.

210. United Nations Convention on the Law of the Sea, Dec. 10, 1982, 1833 U.N.T.S. 397 [hereinafter UNCLOS].

211. Underwater Heritage Convention, supra note 17, art. 8.

212. UNCLOS, supra note 210, art. 33; Lloyd C. Fell, Maritime Contiguous Zones, 62 MICH. L. REV. 848, 850 (1964).

213. Dromgoole, supra note 208 , at 78 n.97.

214. Harm M. Dotinga \& Alex G. Oude Elferink, Current Legal Developments: The Netherlands, 22 INT'L J. MARINE \& COASTAL L. 317, 321 (2007). 
excavation or removal of such objects without a relevant permit, with criminal sanctions attached for infringement. ${ }^{215}$

Finally, under Article 9 of the Underwater Heritage Convention, State Parties have a responsibility to protect underwater cultural heritage in the exclusive economic zone and the continental shelf, which should not extend more than 200 nautical miles. ${ }^{216}$ Responsibility for underwater cultural heritage in this zone entails a reporting obligation on states parties who discover or engage in an activity aimed at such objects. Furthermore, Article 10 grants an overarching right to states parties to prohibit or authorize activity aimed at underwater cultural heritage in their exclusive economic zone. ${ }^{217}$ Essentially, these provisions endeavor to establish a consultative relation between interested States Parties. ${ }^{218}$

As for the jurisdiction of the Underwater Heritage Convention in the case of Palestine, first the rivers or inland seas, including stretches of the River Jordan and the Dead Sea, are within the reach of the Convention. ${ }^{219}$ It remains largely unclear what, if any, underwater cultural heritage can be found in Palestine's inland waters. Evidently, the internal waterways of the West Bank are more commonly examined from a hydro-political and humanitarian viewpoint, ${ }^{220}$ with the River Jordan, for example, being a source of long-running multilateral disputes in which the possible existence of underwater cultural heritage has not been relevant. ${ }^{221}$ Similarly, the Dead Sea is unknown in underwater cultural heritage terms, but is itself a cultural heritage site proposed for inclusion on the World Heritage List. In neighboring Jordan, a recent report under the Underwater Heritage Convention that mentions the Dead Sea, indicated that "no submerged heritage site [has] been detected in Jordan, since no excavations or surveys have been conducted."222 Whilst Israel has not ratified the Underwater Heritage Convention, there is a dedicated Marine Archaeological Unit attached to the Israel Antiquities Authority, ${ }^{223}$ which includes inland waters such as the Dead Sea in its remit, ${ }^{224}$

215. Id. at 323 .

216. UNCLOS, supra note 210 , art. 57.

217. Dromgoole, supra note 208 , at 83.

218. Anastasia Strati, Protection of the Underwater Cultural Heritage: From the Shortcomings of the UN Convention on the Law of the Sea to the Compromises of the UNESCO Convention, in UNRESOLVED ISSUES AND NEW CHALLENGES TO THE LAW OF THE SEA: TIME BEFORE AND TIME AFTER 45 (Anastasia Strati, Maria Gavouneli \& Nikolaos Skourtos eds., 2006).

219. Underwater Heritage Convention, supra note 17, art. 28.

220. See Greg ShaPland, Rivers of Discord: InTERnal Water Disputes in the MidDle EAST 20-27 (1997).

221. See Aaron T. Wolf, Hydropolitics ALONG THE JoRdan River: SCARCE Water AND ITS IMPACT ON THE ARAB-ISRAELI CONFLICT 1 (1995).

222. UNESCO Regional Meeting, Oct. 25-27, 2010, Jordan: National Report on Underwater Cultural Heritage, U.N. Doc. CLT/CIH/MCO/2010/RP/173 (Nov. 12, 2010).

223. See Shelley Wachsmann \& Dan Davis, Nautical Archaeology in Israel, in INTERNATIONAL HANDBOOK OF UNDERWATER ARCHAEOLOGY 500 (Carol V. Ruppé \& Janet F. Barstad eds., 2002).

224. See The Marine Archaeology Branch, ISRAEL ANTIQUITIES AUTHORITY, http://www.antiquit ies.org.il/article_Item_eng.asp?sec_id $=28 \&$ subj_id=233 (last visited Feb. 15, 2013); Introduction to Marine Archaeology in Israel, ISRAEL ANTIQUITIES AUTHORITY, http://www.antiquities.org.il/modules _eng.asp?Module_id=85 (last visited Feb. 15, 2013). 
although there are no reports of any discovery. There has, however, been an important find in the Sea of Galilee in Israel of an ancient 1st century fishing boat, $^{225}$ an indication that internal waters in the region may yield further discoveries.

The immediate relevance of the Underwater Heritage Convention to Palestine is in relation to the Gaza Strip, despite the present inaccessibility of its waters resulting from the maritime blockade. A recent analysis of archaeology in Gaza notes: "a lot of artifacts are not the result of active digging with shovels . . . but of underwater diving."226 Furthermore ancient ships and trade routes in the southeastern Mediterranean have spurred intense interest among underwater archaeologists and explorers. ${ }^{227}$ A 2002 piece by Robert Ballard et al. charts the discovery of two 8th century C.E. Phoenician shipwrecks, named Tanit and Elissa by the team, thirty-three nautical miles off the coast of Gaza. ${ }^{228}$ The wrecks are not within Gaza's territorial waters, nor in its contiguous zone, but they could end up being located within its exclusive economic zone, in the event that Palestine declares one. In such a case, Palestine would have a right "to prohibit or authorize any activity directed at such heritage" located in their exclusive economic zone, in accordance with Article 10(2) of the Underwater Heritage Convention. ${ }^{229}$

The Tanit had a cargo of 385 visible amphoras ${ }^{230}$ used to transport fine wine, while Elissa had 396 amphoras, representing just the top two tiers of the cargo. ${ }^{231}$ To put this in context, the best-known sites on land for ancient amphoras, at Hazor in Israel and Tyre in Lebanon, had revealed sixty whole forms. Ballard's team collected samples with the aim of establishing the size and date of the shipwreck, the nature and origin of the cargo, the home port of the crew, its route and destination, the cause of the shipwreck, and the relationship with the economic network of the Mediterranean. ${ }^{232}$ This led to the conclusion that the Tanit and Elissa potentially marked "an ancient trade route along which other shipwrecks

225. See Shelley Wachsmann, The Sea of Galilee Boat: A 2000 Year Old Discovery FROM THE SEA OF LEGENDS 4, 348 (2000).

226. Fareed Armaly, Crossroads and Contexts: Interviews on Archaeology in Gaza, $37 \mathrm{~J}$. PALESTINE STUD. 43, 54 (2008).

227. See generally id. (discussing archaeologists' and explorers' underwater work).

228. Robert Ballard et al., Iron Age Shipwrecks in Deep Water off Ashkelon, Israel, 106 AM. J. ARCHAEOLOGY 151, 151 (2002).

229. Underwater Heritage Convention, supra note 17, art. 10(2).

230. Ballard et al., supra note 228, at 158; see also Armaly, supra note 226 , for a description of the role of amphoras in establishing the Gazan museum project provided by the Geneva museum curator Marc-André Haldimann: "[O]ur particular interest in Gaza goes back to 1980, when excavations under the Cathedral of Geneva turned up the remains of two wine amphoras from Gaza . . . As to why amphoras from Gaza would be found under the cathedral of Geneva, the explanation is to be found in a text by Grégoire de Tours, who wrote in the sixth century A.D. that the best wine for celebrating the Mass is the wine of Gaza."

231. Ballard et al, supra note 228 , at 158 .

232. Id. at 152 . 
could be found."233 The title of the piece is Iron Age Shipwrecks in Deep Water Off Ashkelon, Israel, yet the Phoenician wrecks should be more properly described as being off the coast of Gaza. There is a topographic map of the wrecks included in the piece, which shows quite clearly that the closest land to the site of the wrecks is Gaza, if a direct line is drawn from the indicated sites to the surrounding coastlines. ${ }^{234}$ Despite the title, the piece itself describes its subject as "shipwrecks in the area of Egypt and the Gaza Strip, 33 nautical miles offshore." ${ }^{235}$ A follow-up paper in a larger study on the history of deep-water archaeology notes how, in 2003, Ballard's team "tried to go back to the site for more detailed archaeological investigations but could not obtain a permit from the Egyptian authorities,"236 marking the total excision of Palestine from the research. Any such explorations would require the prior authorization and involvement of the Palestinian side to be lawful, following its ratification of the Underwater Heritage Convention.

Overall, Palestinian ratification of the Underwater Heritage Convention would provide Palestine with the legal right to assert a contiguous zone for the purposes of underwater cultural heritage protection. Palestine could consider following the example of the Netherlands and explicitly extend the scope of its forthcoming heritage legislation to its territorial seas and the contiguous zone, creating an archaeological zone of control over underwater cultural heritage that extends to twenty-four nautical miles off the coast of Gaza. A dedicated Palestinian underwater archaeological unit should thereby be established to coordinate with researchers and prospective exploration missions, which could conceivably work closely, or be attached to the Gaza archaeological museum. The museum is due to open at the ancient port site of Gaza-Blakhiya in $2017 .^{237}$

\section{CONSEQUENCES OF UNESCO MEMBERSHIP}

Palestine's membership of UNESCO, a specialized agency of the United Nations, significantly contributes to the legal settlement of the question of Palestine's status as a "state" in international law, especially for the purposes of accession to other international institutions or treaties. First, it brings Palestine within the so-called "Vienna formula", outlined by the U.N. Treaty Section of the Office of Legal Affairs in its Summary of Practice of the Secretary-General As Depositary of Multilateral Treaties:

when a treaty is open to "States", how is the Secretary-General to determine which entities are States? If they are Members of the United Nations or Parties to the Statute of the International Court of Justice, there is no ambiguity. However, a difficulty has occurred as to possible participation in treaties when entities which appeared otherwise to be

233. Id. at 156. Ballard surmises that the ships could also be the "famous 'ships of Tarshish' mentioned in the Bible." Id. at 166.

234. Id. at 152.

235. Id. at 151 .

236. SOREIDE, supra note 205 , at 45 .

237. See Armaly, supra note 226 , at 44 . 
States could not be admitted to the United Nations, nor become Parties to the Statute of the International Court of Justice owing to the opposition, for political reasons, of a permanent member of the Security Council. Since that difficulty did not arise as concerns membership in the specialized agencies, where there is no "veto" procedure, a number of those States became members of specialized agencies, and as such were in essence recognized as States by the international community. Accordingly, and in order to allow for as wide a participation as possible, a number of conventions then provided that they were also open for participation to States members of specialized agencies .... This type of entry-into-force clause [i]s called the "Vienna formula." 238

Any treaty that follows the "Vienna formula" can be signed and ratified by Palestine by virtue of its membership of UNESCO. There remains a question as to treaties that do not expressly follow the "Vienna formula," including the Rome Statute of the International Criminal Court, which states only that the instrument is open for signature by "all States" in its Article 125(1). Schabas cites the Summary of Practice of the Secretary-General: ${ }^{239}$

Nevertheless, a number of treaties adopted by the General Assembly were open to participation by "all States" without further specifications . ... In reply to questions raised in connection with the interpretation to be given to the all States formula, the Secretary-General has on a number of occasions stated that there are certain areas in the world whose status is not clear. If he were to receive an instrument of accession from any such area, he would be in a position of considerable difficulty unless the Assembly gave him explicit directives on the areas coming within the "any State" or "all States" formula. He would not wish to determine, on his own initiative, the highly political and controversial question of whether or not the areas whose status was unclear were States. Such a determination, he believed, would fall outside his competence. He therefore stated that when the "any State" or "all States" formula was adopted, he would be able to implement it only if the General Assembly provided him with the complete list of the States coming within the formula, other than those falling within the "Vienna formula." 240

The phrase "other than those falling within the "Vienna formula"' means that for the Secretary-General, ambiguity lies only with those states that do not satisfy

238. U.N. Treaty Section of the Office of Legal Affairs, Summary of Practice of the SecretaryGeneral as Depositary of Multilateral Treaties, ๆ 79, U.N. Doc. ST/LEG/7/Rev.1 (1999) [hereinafter Summary of Practice]. The "Vienna formula" is drawn from the Vienna Convention on the Law of Treaties. According to Article 81 of that instrument, "[t]he present Convention shall be open for signature by all States Members of the United Nations or of any of the specialized agencies." Vienna Convention on the Law of Treaties, art. 81, May 23, 1969, 1155 U.N.T.S. 331.

239. Schabas, supra note 2 (citing Summary of Practice).

240. Summary of Practice, supra note $238, \uparrow 81$, at 23. 
the "Vienna formula." Hence the Secretary-General's depository practice "makes it clear that admission to UNESCO would be satisfactory as far as the SecretaryGeneral is concerned" to enable Palestine to ratify the international treaties for which the Secretary-General acts as depositary. ${ }^{241}$ Schabas proceeds to note, "[UNESCO] membership is 'fully representative of the international community' and any guidance from the General Assembly would be 'substantially identical' to the position taken by UNESCO . . . . Thus, nothing stands in the way of Palestine acceding to the Rome Statute except Palestine itself.",242

In its preliminary examination of Palestine's declaration transferring jurisdiction to the International Criminal Court for "acts committed on the territory of Palestine since 1 July 2002," pursuant to Article 12(3) of the Rome Statute, the Prosecutor deferred its determination of Palestine's status as a state. It did so in its 3 April 2012 update on the "Situation in Palestine," and left the question of Palestine's status as a state for the purpose of the Rome Statute to the U.N. bodies, or, the Court's Assembly of State Parties. ${ }^{243}$ The Prosecutor set out his rationale as follows:

In accordance with article 125, the Rome Statute is open to accession by "all States", and any State seeking to become a Party to the Statute must deposit an instrument of accession with the Secretary-General of the United Nations. In instances where it is controversial or unclear whether an applicant constitutes a "State," it is the practice of the SecretaryGeneral to follow or seek the General Assembly's directives on the matter. This is reflected in General Assembly resolutions, which provide indications of whether an applicant is a "State." Thus, competence for determining the term "State" within the meaning of article 12 rests, in the first instance, with the United Nations Secretary General who, in case of doubt, will defer to the guidance of the General Assembly.

[T] he current status granted to Palestine by the United Nations General Assembly is that of "observer," not as a "Non-member State." The Office understands that on 23 September 2011, Palestine submitted an application for admission to the United Nations as a Member State in accordance with article 4(2) of the United Nations Charter, but the Security Council has not yet made a recommendation in this regard. While this process has no direct link with the declaration lodged by Palestine, it informs the current legal status of Palestine for the interpretation and application of article 12.

The Office could in the future consider allegations of crimes committed in Palestine, should competent organs of the United Nations or

241. Schabas, supra note 2.

242. Id.

243. Situation in Palestine, supra note 3, ๆ| 1-2. 
eventually the Assembly of States Parties resolve the legal issue relevant to an assessment of article $12 .{ }^{244}$

The Prosecutor's position was that Palestine must await a decision of the U.N. General Assembly, or alternatively Palestine's application for full U.N. membership, which was shelved by the Security Council in late 2012, to satisfy the Prosecutor's self-assigned criteria for a self-referral under Article 12(3), and that UNESCO membership in itself is not sufficient. Pursuant to this rationale, the 29 November 2012 General Assembly resolution granting Palestine "non-member state status" in the United Nations resolves this requirement. The current International Criminal Court Prosecutor, Fatou Bensouda, articulated the present state of affairs at a public conference in March 2013: "the ball is now in the court of Palestine;" "Palestine has to come back;" and, "we are waiting for them."245

Notwithstanding the Prosecutor's update and the particular question of the International Criminal Court, Palestine's full membership of UNESCO creates a precedent to be relied on for it to join other U.N. specialized agencies, as well as to accede to international treaties. For instance, Palestine can move beyond UNESCO treaties by ratifying UNCLOS, whose formula in Article 305(1)(a) indicates that it is open for signature by "all States;" as noted, the SecretaryGeneral, the depository of UNCLOS, considers this to include those covered by the "Vienna formula."

As part of its membership of UNESCO, in January 2011, Palestine submitted accession instruments to four UNESCO conventions, which it has now ratified: the 1972 Convention Concerning the Protection of World Cultural and Natural Heritage, the 2001 Convention on the Protection of the Underwater Cultural Heritage, the 2003 Convention for the Safeguarding of the Intangible Cultural Heritage, and the 2005 Convention on the Protection and Promotion of the Diversity of Cultural Expressions. In March 2012, it also acceded to the 1970 Convention on the Means of Prohibiting and Preventing the Illicit Import, Export and Transfer of Ownership of Cultural Property, which it has now ratified, and a the 1954 Hague Convention and its two protocols, which are being processed at the time of writing. Gaining access to further institutional frameworks within UNESCO, and claiming the substantive rights guaranteed in these instruments, provides Palestine with further means to assert its sovereign rights over its internationally-recognized territory. At the very least, the legitimate Palestinian representatives would be able to claim respect for their rights to control, protect and explore their cultural and natural heritage, as well as take part in deliberations that might entail Palestinian heritage located within the internationally-recognized territory of Israel.

244. Id. ๆ $5,7-8$.

245. The current ICC Prosecutor made these statements during a public discussion held at the Academie Diplomatique Internationale in Paris on March 20, 2013. John V. Whitbeck, Palestine and the ICC, AL JAZEERA ENGLISH (April 16, 2013), http://www.aljazeera.com/indepth/opinion/2013/04/2 $01341561759725150 . \mathrm{html}$. 
An example of a readily-accessible UNESCO mechanism that Palestine could use to further protection for its heritage is the World Heritage List. In this respect, the UNESCO field office in Ramallah has focused on building the capacity of Palestinian institutions in view of the future implementation of the World Heritage Convention. ${ }^{246}$ An Inventory of Palestinian Heritage of Potential Outstanding Universal Value, consisting of twenty sites, was submitted to the World Heritage Committee in 2005. ${ }^{247}$ On 26 January 2011, the Palestinian Ministry of Tourism and Antiquities submitted the nomination file to the World Heritage Centre for Bethlehem's old city, ${ }^{248}$ which was approved in June 2012 when Bethlehem's Nativity Church and Pilgrimage route became the first Palestinian sites to be included on the List. ${ }^{249}$ According to a December 2012 report, UNESCO is currently also considering the inclusion of the ancient terraces of the West Bank village of Battir for inclusion on the List. ${ }^{250}$ A file for the old city of Hebron is currently under preparation. ${ }^{251}$

Having ratified the World Heritage Convention, ${ }^{252}$ Palestine's inventory can become official and the nomination of sites for inscription on the World Heritage List can be initiated. ${ }^{253}$ Normally, the nomination process takes a number of years. ${ }^{254}$ The nomination of sites entails substantial work on their documentation to demonstrate that proper legal and management provisions exist to ensure their conservation. In June 2011, Palestine submitted information to the World Heritage Committee on progress made in the implementation of the activities in favor of the protection of certain sites. ${ }^{255}$ Despite Israel's inclusion of sites located in

246. Hamdan Taha, World Heritage in Palestine: From Inventory to Nomination, THIS WEEK IN PALESTINE (Mar. 2011), http://thisweekinpalestine.com/details.php?id=3349\&ed=192\&edid=192.

247. Id.

248. Id.

249. Bethlehem \& the Nativity: The Story of Inscribing Bethlehem on the World Heritage List, BETHLEHEM IS WORLD HERITAGE, http://www.bethlehem-whs.pna.ps/index.php?option=com_content\& view=article \&id=54\&Itemid=55 (last visited May 8, 2013).

250. Nir Hasson, UNESCO Likely to Recognize West Bank Village's Terraces as Heritage Site, HAARETZ (Dec. 6, 2012), http://www.haaretz.com/news/diplomacy-defense/unesco-likely-to-recognizewest-bank-village-s-terraces-as-heritage-site.premium-1.482857.

251. Chiara De Cesari, World Heritage and National Sovereignty: On Palestine's UNESCO Bid, LEIDEN-STANFORD HERITAGE NETWORK (Dec. 6, 2011), http://www.networkedheritage.org/2011/12/0 6/world-heritage-and-national-sovereignty-on-palestine $\% \mathrm{E} 2 \% 80 \% 99 \mathrm{~s}$-unesco-bid/.

252. Convention Concerning the Protection of the World Cultural and Natural Heritage, Nov. 16, 1972, 27 U.S.T. 37, 1037 U.N.T.S. 151. Palestine ratified the Convention in December 2011; its membership became active in March 2012. U.N. Office of International Standards and Legal Affairs, Ratification by Palestine of the Convention Concerning the Protection of the World Cultural and Natural Heritage, UNESCO.oRG (Jan. 16, 2012), http://portal.unesco.org/en/ev.php-URL_ID=48775\& URL DO=DO_TOPIC\&URL_SECTION=201 html.

253. Palestine and the World Heritage Convention, UNESCO.ORG (Dec. 12, 2011), http://whc.une sco.org/en/news/821.

254. Id. See Sam Litton, Note, The World Heritage "In Danger" Listing as a Taking, 44 N.Y.U. J. INT'L L. \& POL. 219, 219 (2011) (discussing in detail the "In Danger" listing regime).

255. World Heritage Comm., United Nations Educational, Scientific and Cultural Organization Convention Concerning the Protection of the Palestinian Cultural and Natural Heritage, June 19-29, 
Palestinian territory on Israel's Ministry of Tourism list of sites, UNESCO has held the unequivocal position that no site in the Palestinian territory can be listed by Israel. ${ }^{256}$

UNESCO's conventions offer a framework of control and protection through the law over Palestine's cultural and natural heritage. By defining the relations between the parties in terms of their control and rights over cultural and natural heritage, UNESCO's framework ensures that the sovereign population remains in relative control of their cultural property and heritage during armed conflict and prolonged belligerent occupation. Palestine's pending ratification of the 1954 Hague Convention and its First Protocol, as well as the 1999 Second Protocol, would also mandate the restitution of artifacts removed from the occupied Palestinian territory, located in the hands of individuals or institutions in Israel or third states. Palestine's inclusion in these international fora would further compliance by third party states, signatories to UNESCO's conventions, who could be required to undertake the seizure of imported artifacts originating in occupied territory, prohibit their exhibition in national museums and, in some cases, demand their return to Palestine. ${ }^{257}$ The Sinai Agreement could be taken as a template to ensure that artifacts from the occupied territories, which have been processed and documented in particular by the Israel Museum, are returned to Palestinian hands. Concurrently, the Palestinian Department of Antiquities and Cultural Heritage can coordinate with the International Council of Museums to put museums worldwide on notice with regards to illegally removed artifacts and their international exhibition.

Palestine can also ratify the 1970 UNESCO Convention and UNIDROIT 1995 to protect against future theft or illegal export. UNIDROIT 1995 provides a forum for the restitution of stolen goods and the return of illegally exported goods outside Palestine through the domestic courts of states parties. Finally, under the Underwater Heritage Convention, which Palestine has ratified, it can assert control over its territorial seas and establish a contiguous zone up to twenty-four nautical miles for the protection of underwater cultural heritage. Palestine also has the option of ratifying UNCLOS that would underline sovereignty over territorial seas and allow the proclamation of a contiguous zone for a range of discovery activities.

2011, Item 11 of the Provisional Agenda: Protection of the Palestinian Cultural and Natural Heritage, U.N. Doc. WHC-11/35.COM/11 (May 27, 2011).

256. See Press Release, UNESCO, Executive Board Adopts Five Decisions Concerning UNESCO's Work in the Occupied Palestinian and Arab Territories, UNESCO Press Release (Oct. 21, 2010), available at http://www.unesco.org/new/en/media-services/single-view/news/executive_board_ adopts_five_decisions_concerning_unescos_work_in_the_occupied_palestinian_and_arab_territories/ (stating that UNECSO classified Rachel's Tomb/Bilal bin Rabah as a mosque and said that it forms "an integral part of the occupied Palestinian territory").

257. Another venue open to Palestine in this regard is UNESCO's Intergovernmental Committee for Promoting the Return of Cultural Property to its Countries of Origin or its Restitution in case of Illicit Appropriation. See Intergovernmental Committee for Promoting the Return of Cultural Property to its Countries of Origin or its Restitution in Case of Illicit Appropriation, UNESCO.ORG, http://portal.unesco.org/culture/en/ev.php-URL_ID=35283\&URL_DO=DO_TOPIC\&URL_SECTION= 201.html (last updated Sept. 23, 2010, 7:55 AM). 
Most recently, Palestine has become a full member of the International Union for Conservation of Nature, ${ }^{258}$ an important step given the effects that the Separation Wall, settlements, and their ensuing infrastructure have had on the Palestinian landscape. One of the most urgent steps, recalled by the UNESCO Ramallah office, is the drafting and promulgation of a new Palestinian law on cultural heritage protection, which would be widely sensitized to ensure the effective combat of looting of sites; notably, enforcement activities for such a law would be limited so long as Israel maintains effective control over the territory.

Effective protection for Palestinian heritage can only be attained by reconnecting the Palestinian people with their cultural and natural heritage. The UNESCO framework combines to support the principal Palestinian interest of regaining control and possession over cultural heritage, and ensuring that it is managed under Palestinian sovereignty and governed by Palestinian law, in accordance with international standards. Along with its ratification of the specialized UNESCO instruments, Palestine should seriously consider the ratification of other international treaties, including human rights conventions, which would provide an important complement to the UNESCO framework by strengthening protection for cultural rights, inter alia. The International Covenant on Economic, Social and Cultural Rights displays the "Vienna formula", reading in Article 26(1): "The present Covenant is open for signature by any State Member of the United Nations or member of any of its specialized agencies."

\section{CONCLUSION}

UNESCO membership represents an important progression for Palestine. By asserting its possession of rights, claiming respect for these rights, and engaging in legal relations-through accession to international organizations and conclusion of treaties-Palestine is both substantiating and operationalizing its international legal personality. In doing so, Palestine is also gaining additional tools to assert the rights it formally enjoys and should be able to exercise, as an internationally recognized state, with well over 130 bilateral state recognitions. Indeed, the effects of Palestine's membership of UNESCO and its accession to UNESCO's international conventions are broader than its specific thematic focus.

Palestine's UNESCO membership has facilitated its participation as an observer in the June 2012 meeting of the State Parties to the Convention on the Law of the Sea, which was objected to by Canada, the United States and Israel, the latter referring to the upgrade as an act of "political posturing." 259 The 29

258. Nasouh Nazzal, Palestine Becomes Member of International Union for Conservation of Nature, GulF NEWS (Feb. 12, 2012), http://gulfnews.com/news/region/palestinian-territories/palestinebecomes-member-of-international-union-for-conservation-of-nature-1.979595.

259. Press Release, Dep't. of Pub. Info., Law of Sea Convention States Parties Open Session Amid Praise for Tribunal's Landmark Boundary Ruling, Seabed Disputes Chambers' Advisory Opinion, U.N. Press Release SEA/1986 (June 4, 2012). See also Press Release, Dep't. of Pub. Info., Law of Sea States Parties Fill One More Seat on Continental Shelf Commission, As Work Continues to Hammer Out Budget for International Tribunal, U.N. Press Release SEA/1972 (June 7, 2012). 
November 2012 General Assembly resolution has, in turn, furthered this process by strengthening Palestine's status as a state in international law, including for the purpose of the International Criminal Court Prosecutor's self-assigned requirements.

The initial implications are the imposition of a wide protective framework around Palestine's cultural and natural heritage, as well as an established mechanism for restitution and prevention of future theft or illegal export of artifacts. Palestine should seek to fortify this protection framework by ratifying other international rights conventions guaranteeing the enjoyment of social and cultural rights. Such steps not only constitute an expression of Palestinian sovereignty in the spirit of what is termed Palestine's "U.N. bid," but also represent a means of moving beyond the cultural property protection framework to propel the integration of the State of Palestine within the international legal order. 